\title{
Images of the U.S. Geological Survey, 1879-1979
}
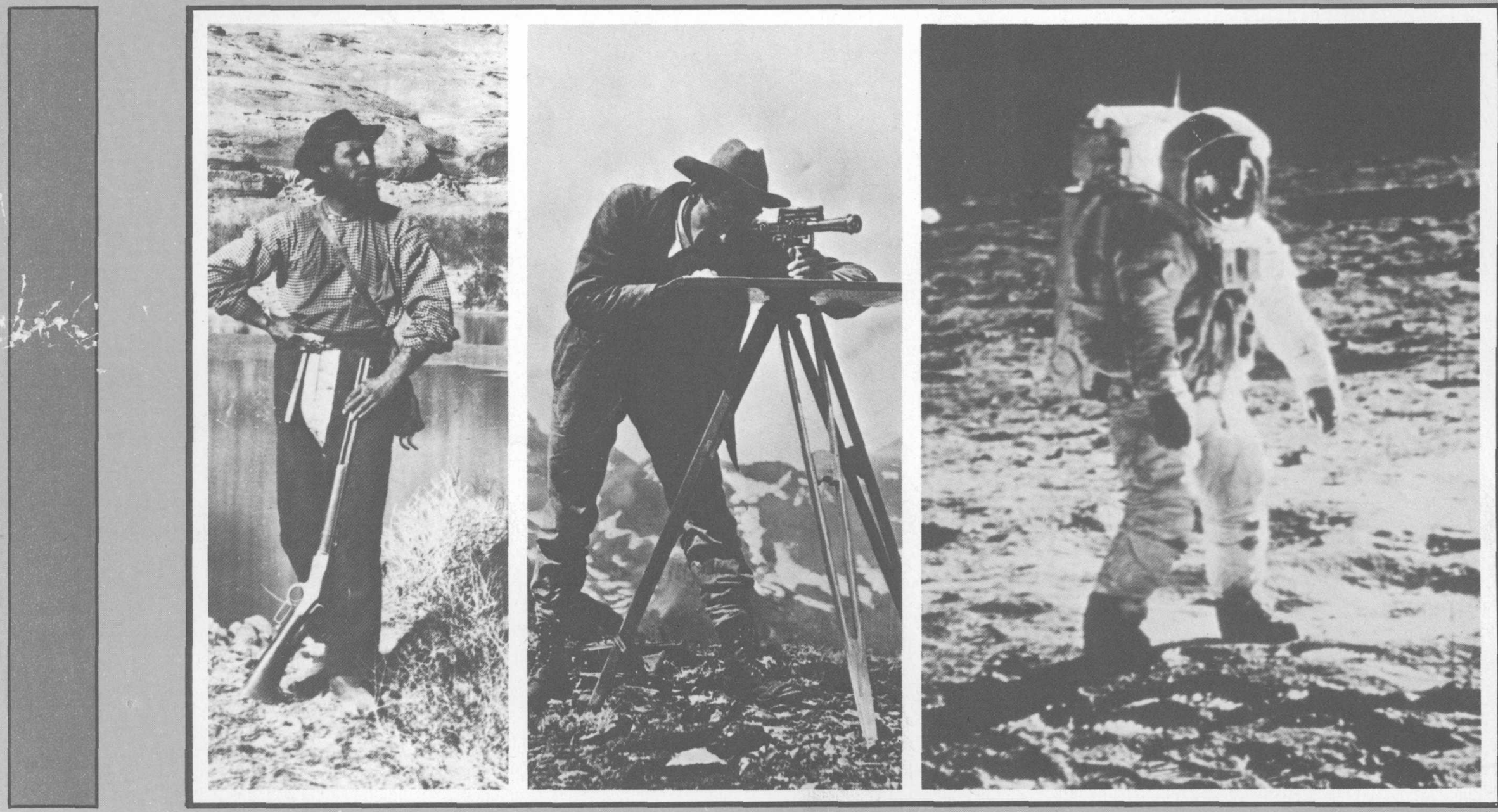

U.S. Department of the Interior/Geological Survey 



\section{Images of the U.S. Geological Survey, 1879-1979}

by E. L. Yochelson and C. M. Nelson

This collection of photographs reflects 100 years of public service by the U.S. Geological Survey since its founding on

March 3, 1879: “. . . for the classification of the public lands, and examination of the geological structure, mineral resources, and products of the national domain." 
The U.S. Geological Survey was founded on March 3,1879, to consolidate some of the functions of the several Federal surveys that were conducted in the West after the Civil War. The newly organized Survey continued to study the Grand Canyon area

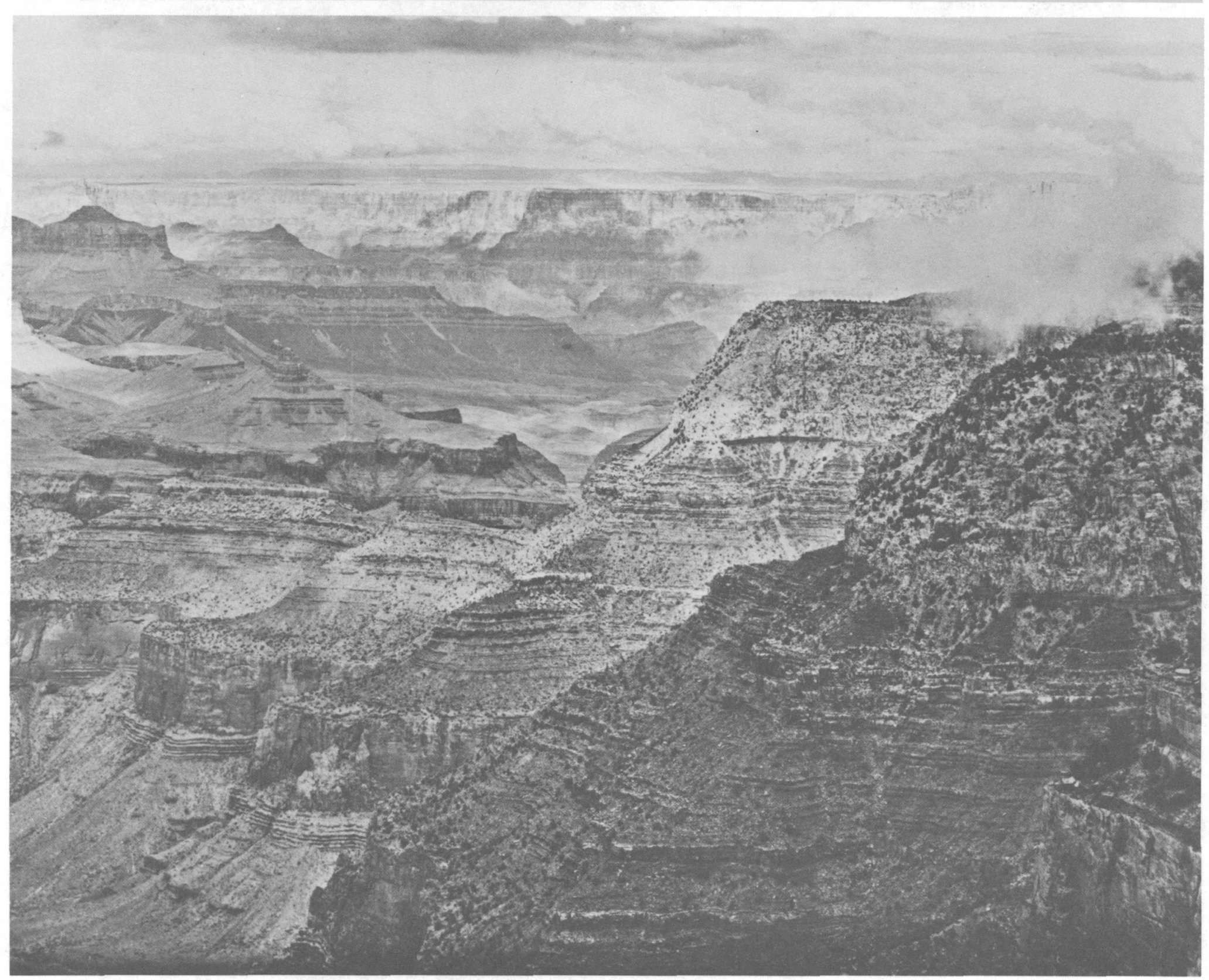


...... to answer questions posed by John Wesley Powell's exploration of the Colorado Plateau country begun in 1869 .

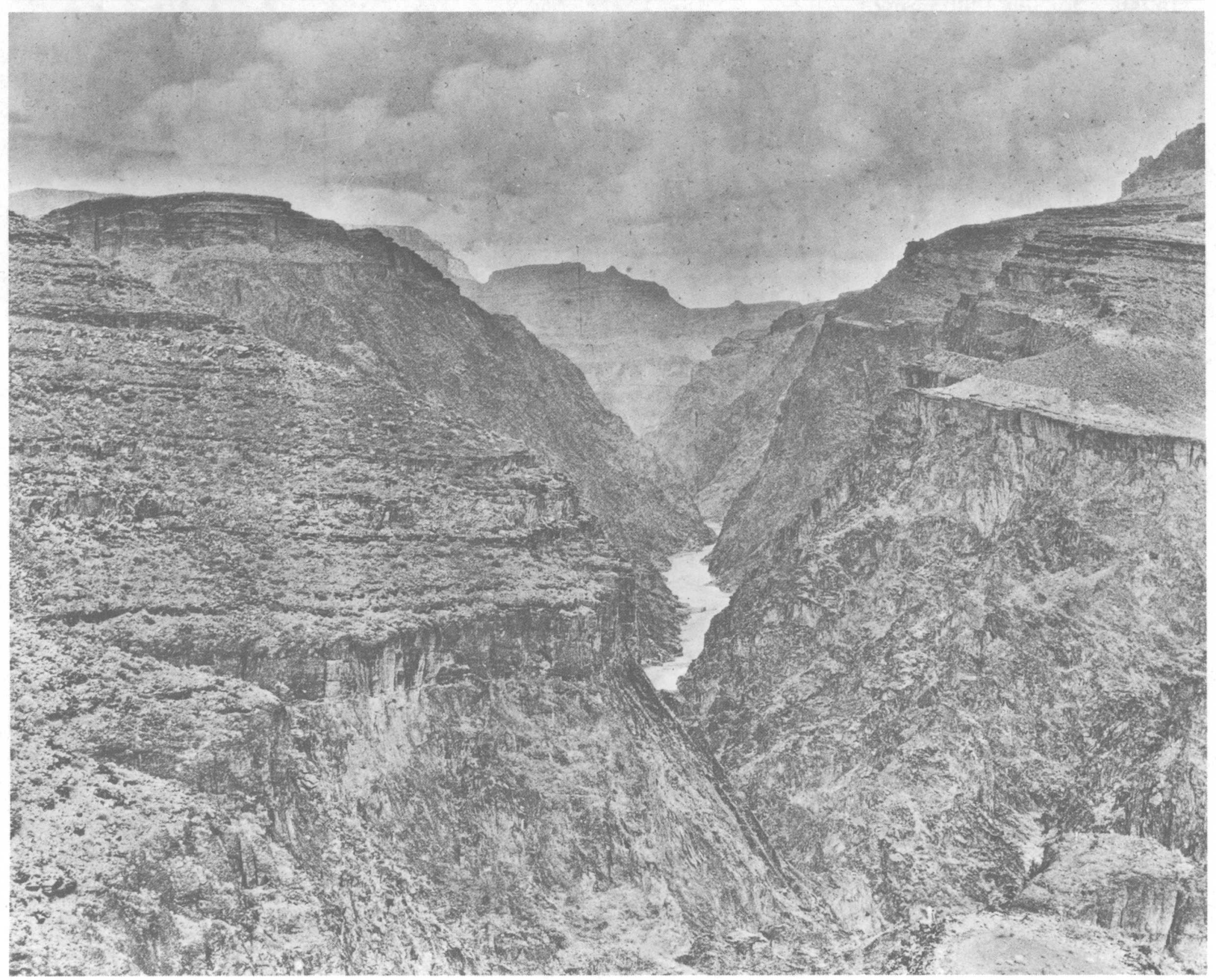


Under Clarence King, its first Director, the Geological Survey continued investigations of significant mining districts, an interest King had pursued as head of the earlier U.S. Geological Exploration of the Fortieth Parallel. King also extended the new agency's work nationally by gathering mineral statistics for the 1880 census.
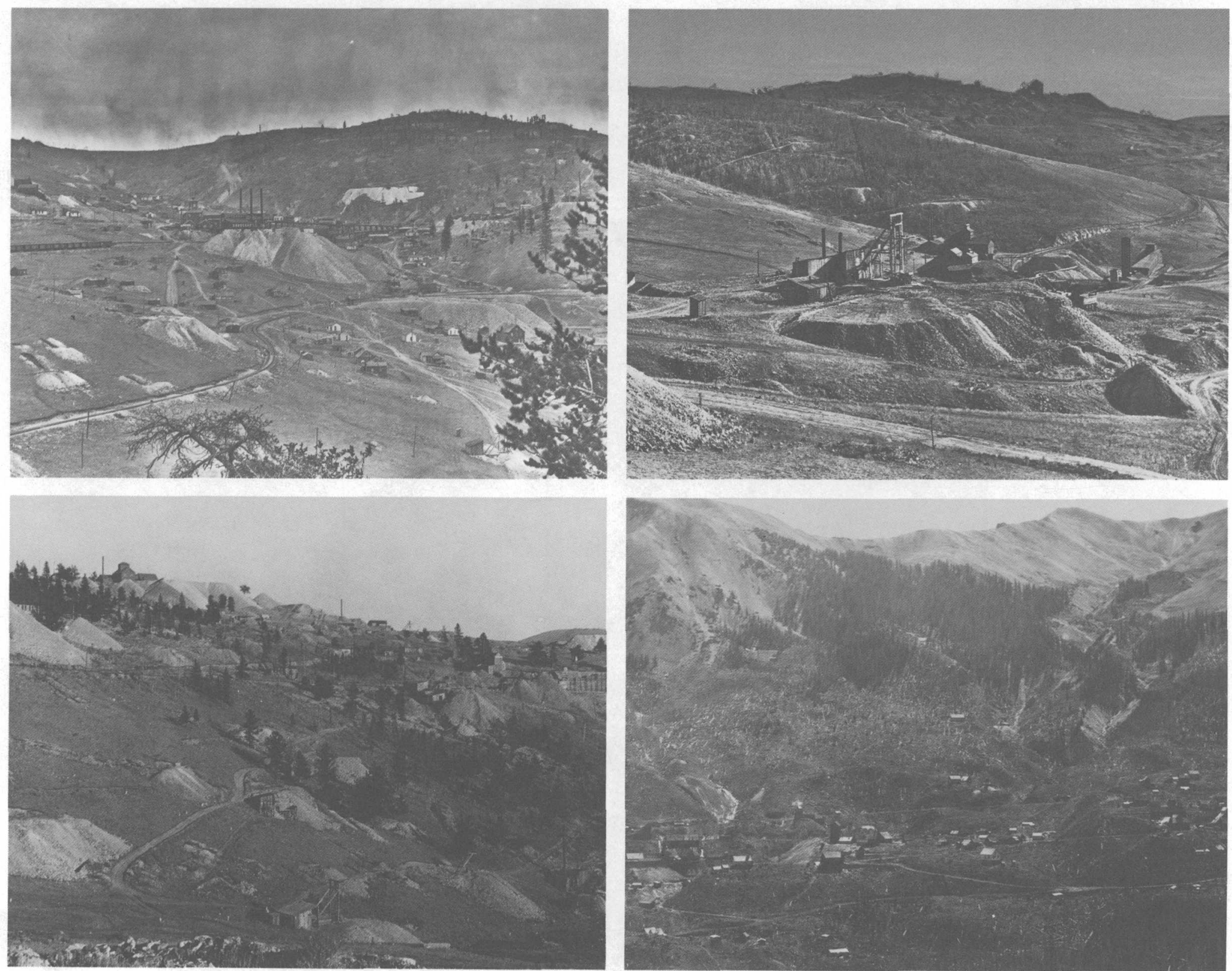
Investigations of Yellowstone National Park continued studies begun by F. V. Hayden's U.S. Geological and Geographical Survey of the Territories, First Division.

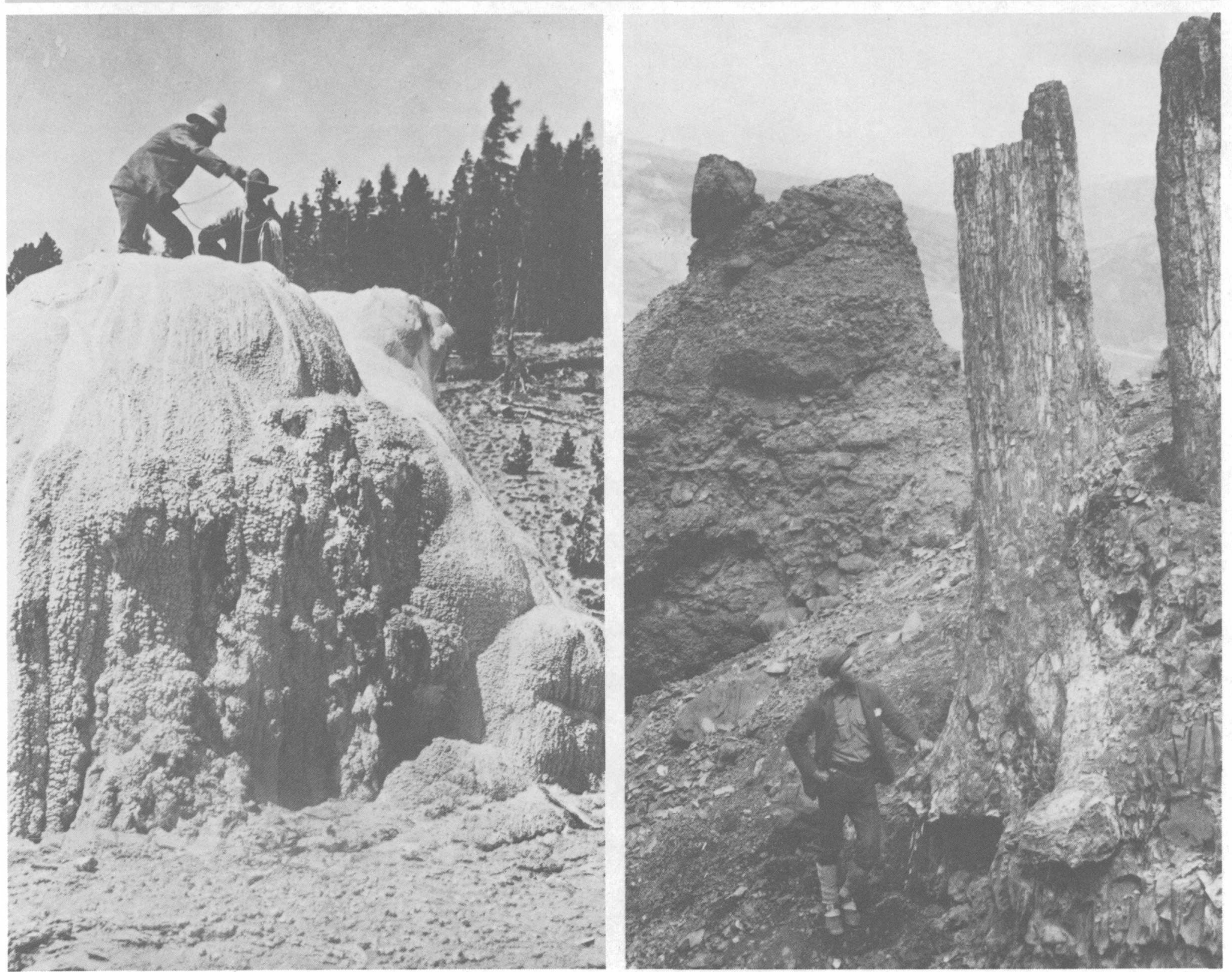


Studies of the Colorado Plateau extended work originated by Powell's Second Division of that territorial survey.

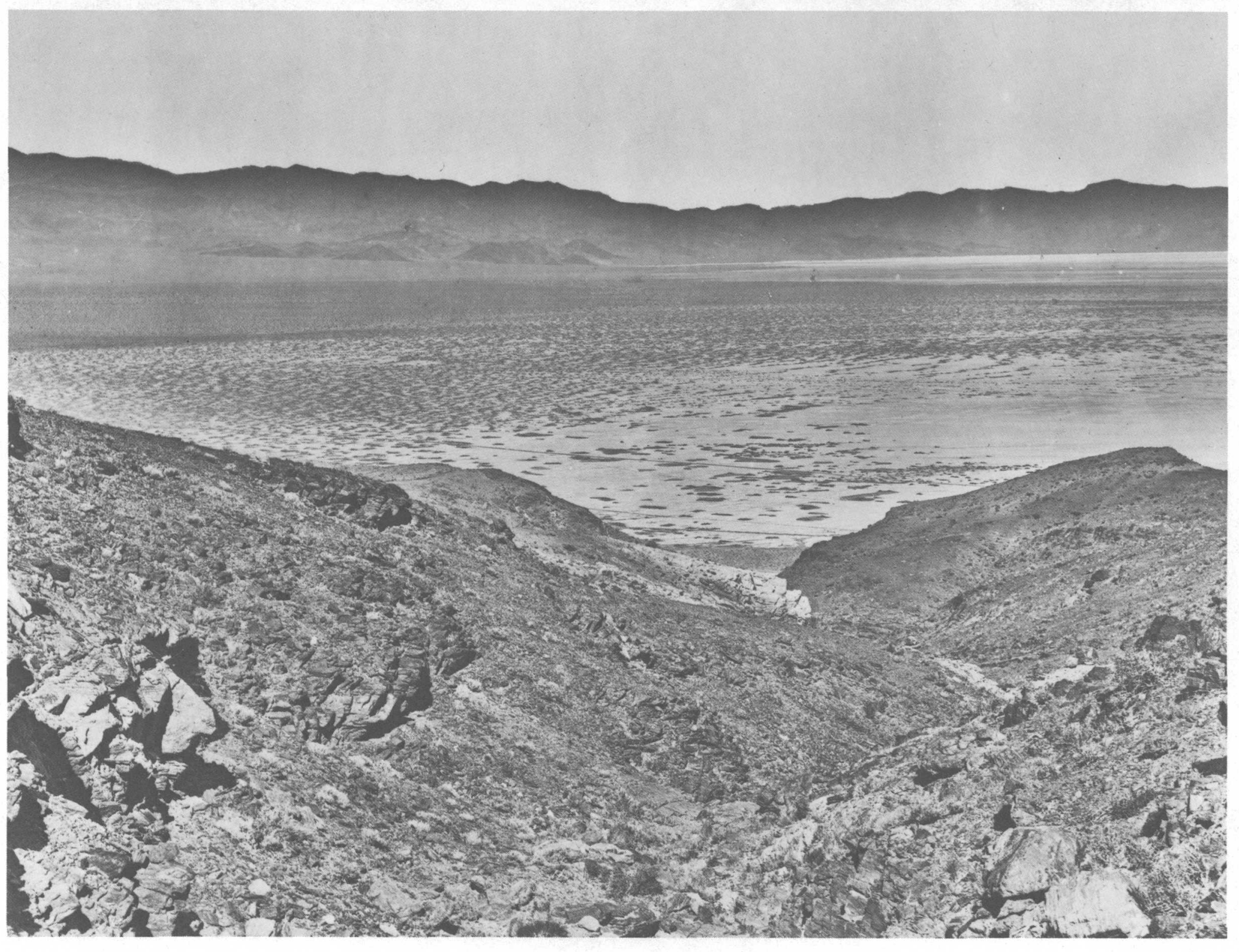


Interest in the Great Basin stemmed in part from 1st Lieutenant George M. Wheeler's U.S. Geographical Surveys West of the One Hundredth Meridian, plus the King and Powell Surveys. Powell, the Geological Survey's second Director, obtained Congressional authority to work throughout the United States to complete a national geologic map but, like King, he was especially interested in the West.

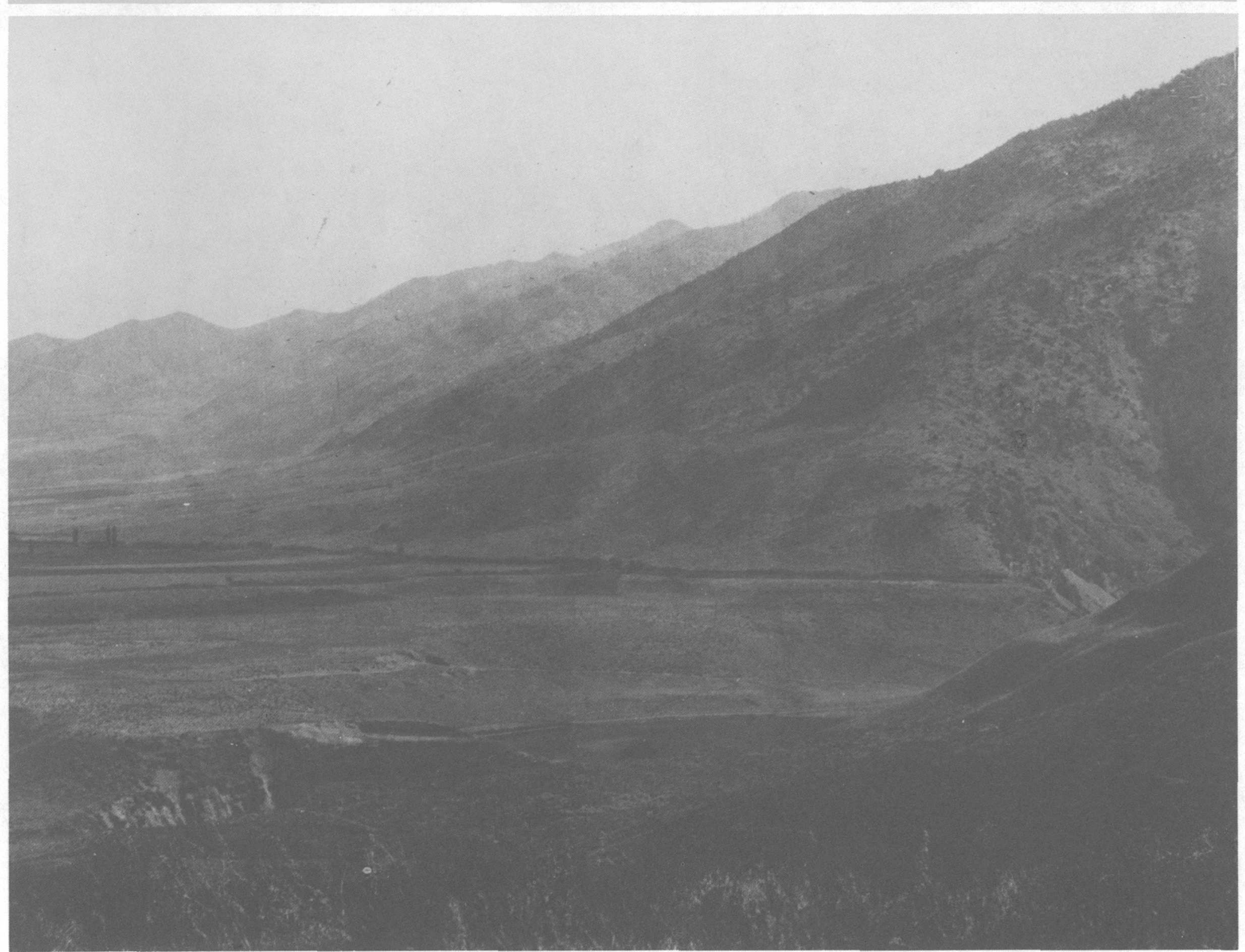




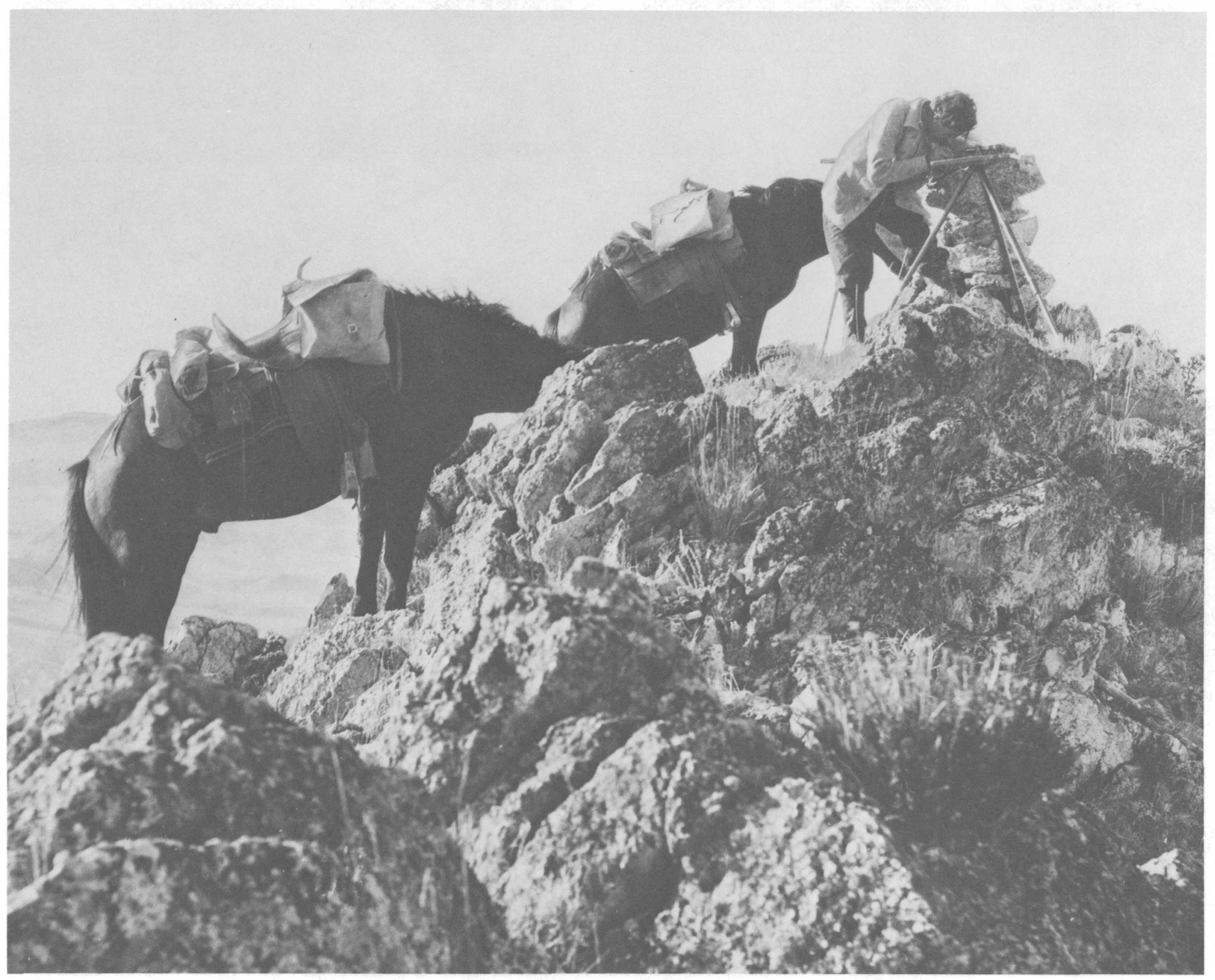

Topographers in the field 


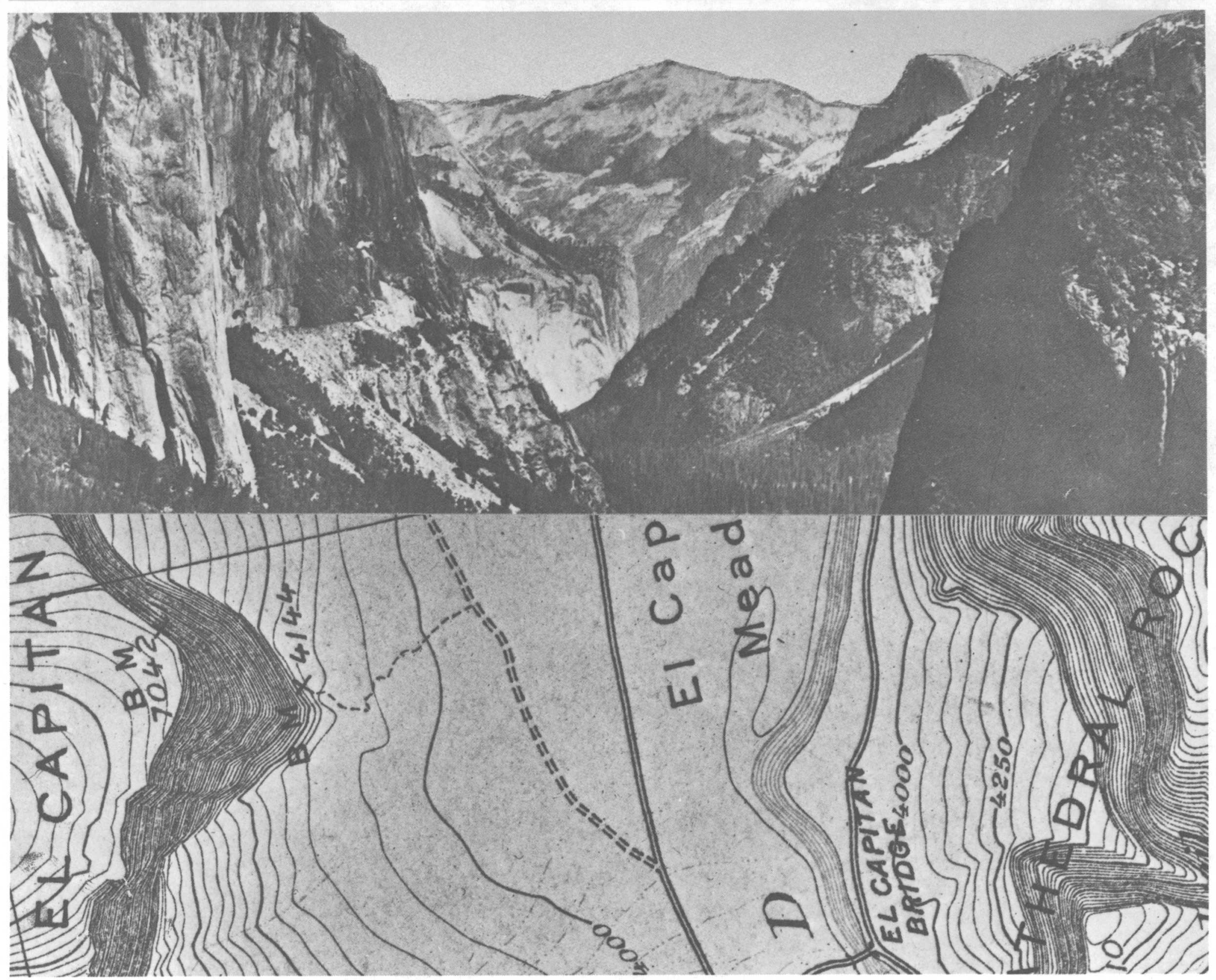




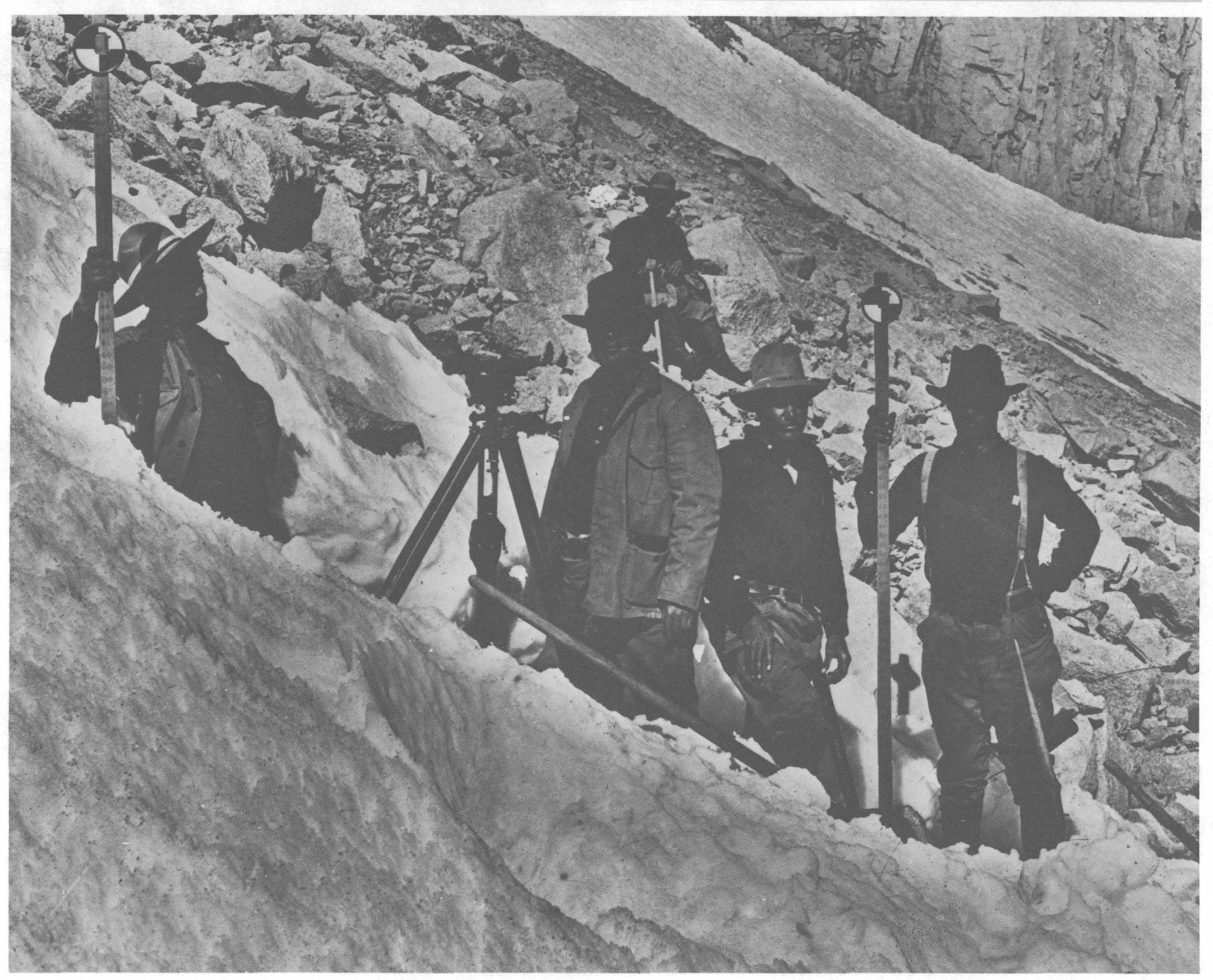


Powell first quartered the new and growing agency at the Smithsonian Institution but soon moved to the Hooe and Adams Buildings on F Street, NW., Washington, D.C., where the Survey remained until 1917.

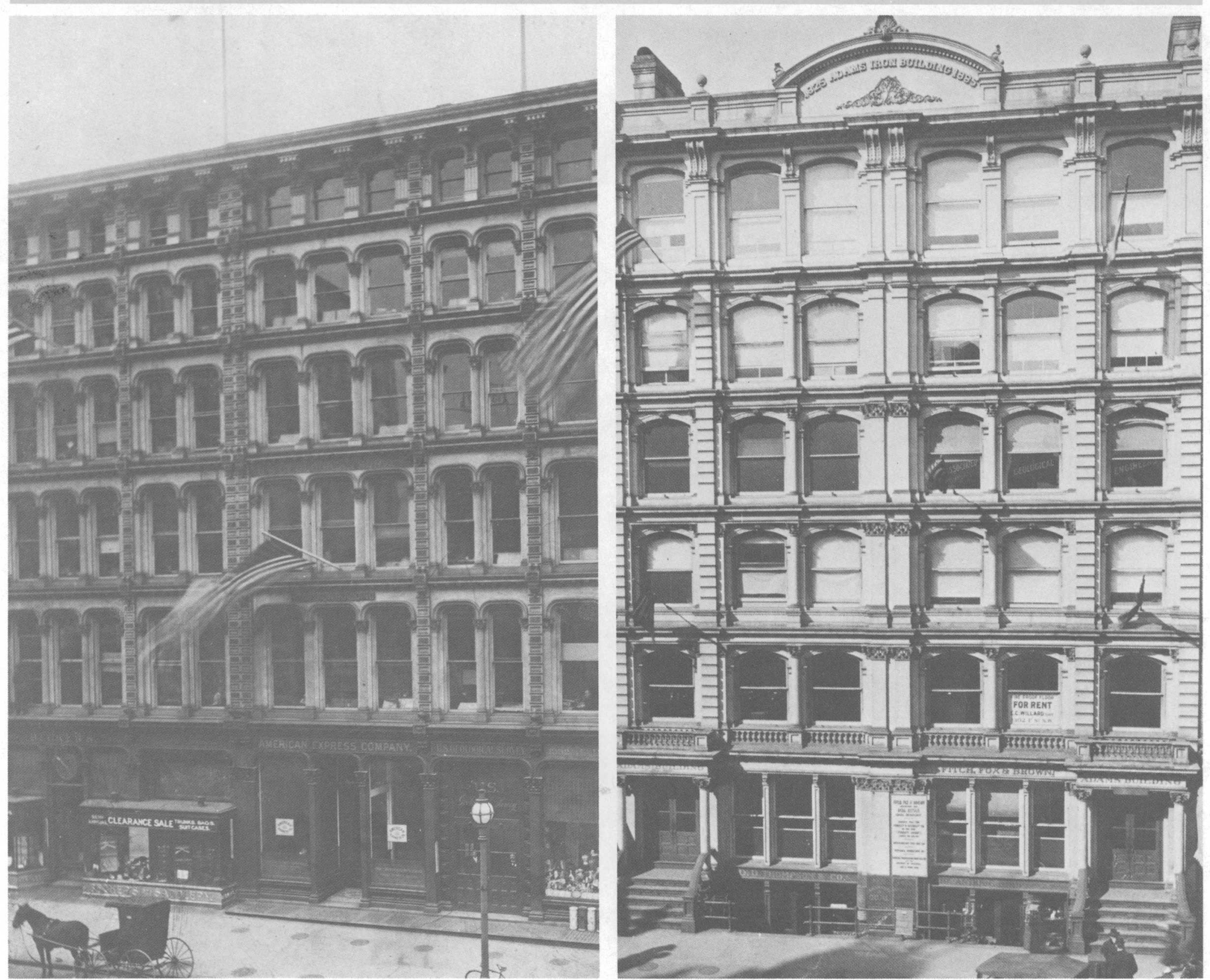

Work during winters in the Washington, D.C. headquarters 

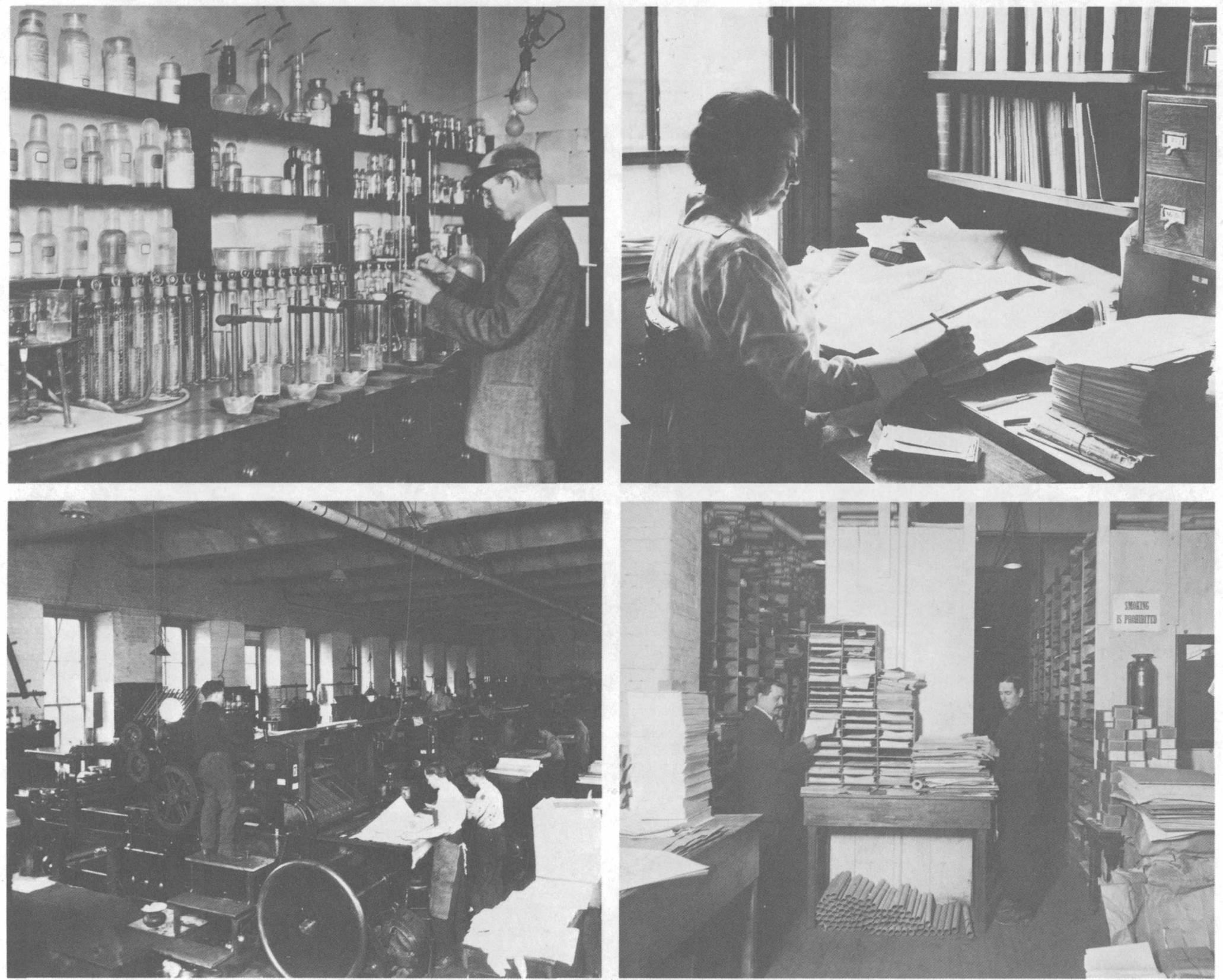
In the 1890's, the Geological Survey began extensive field investigations in the East, particularly of the mineral resources in the southern Appalachian Mountains. These investigations were documented in a series of publications called Geologic Folios which included maps of geologic structure.
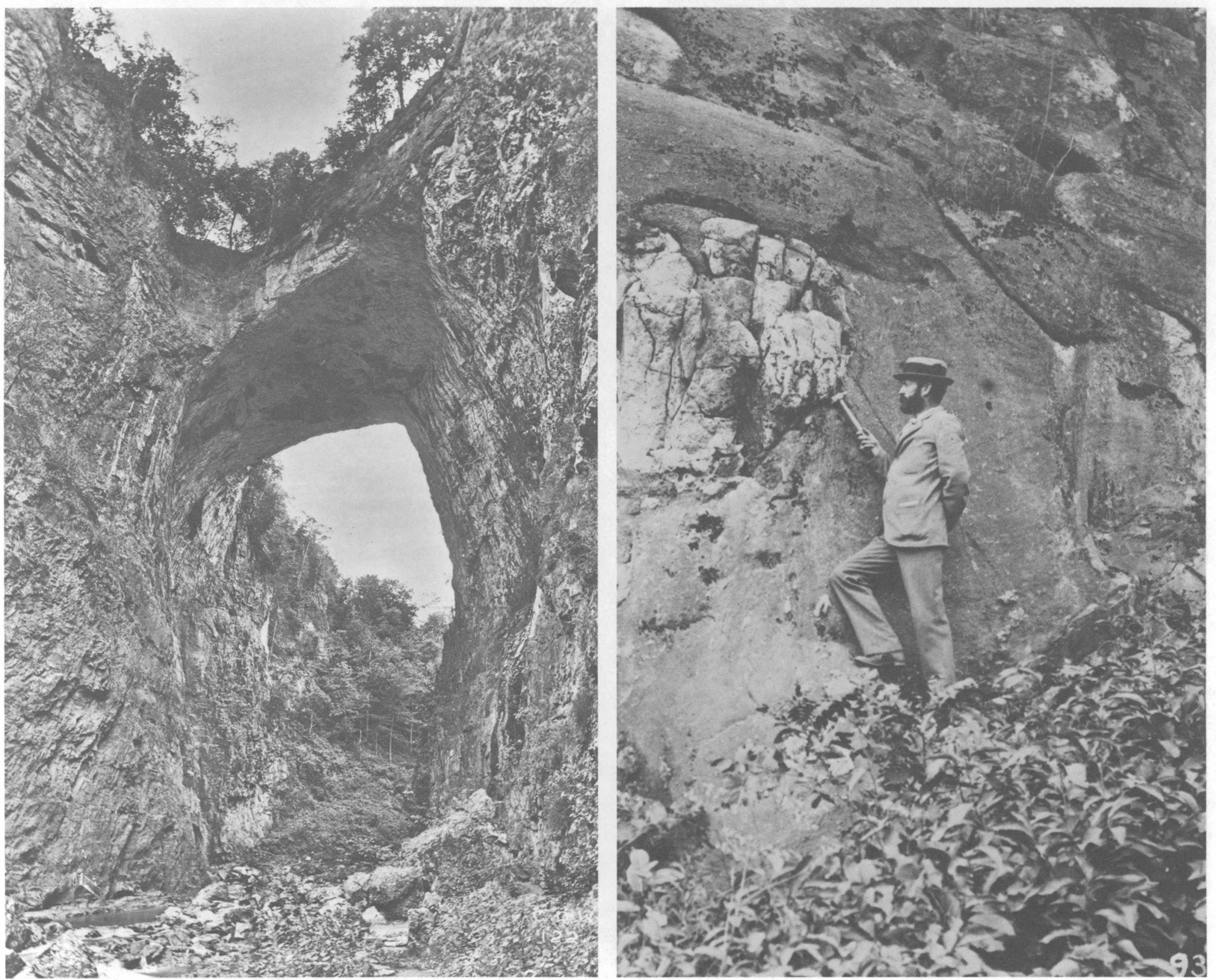

Studies in the eastern United States 


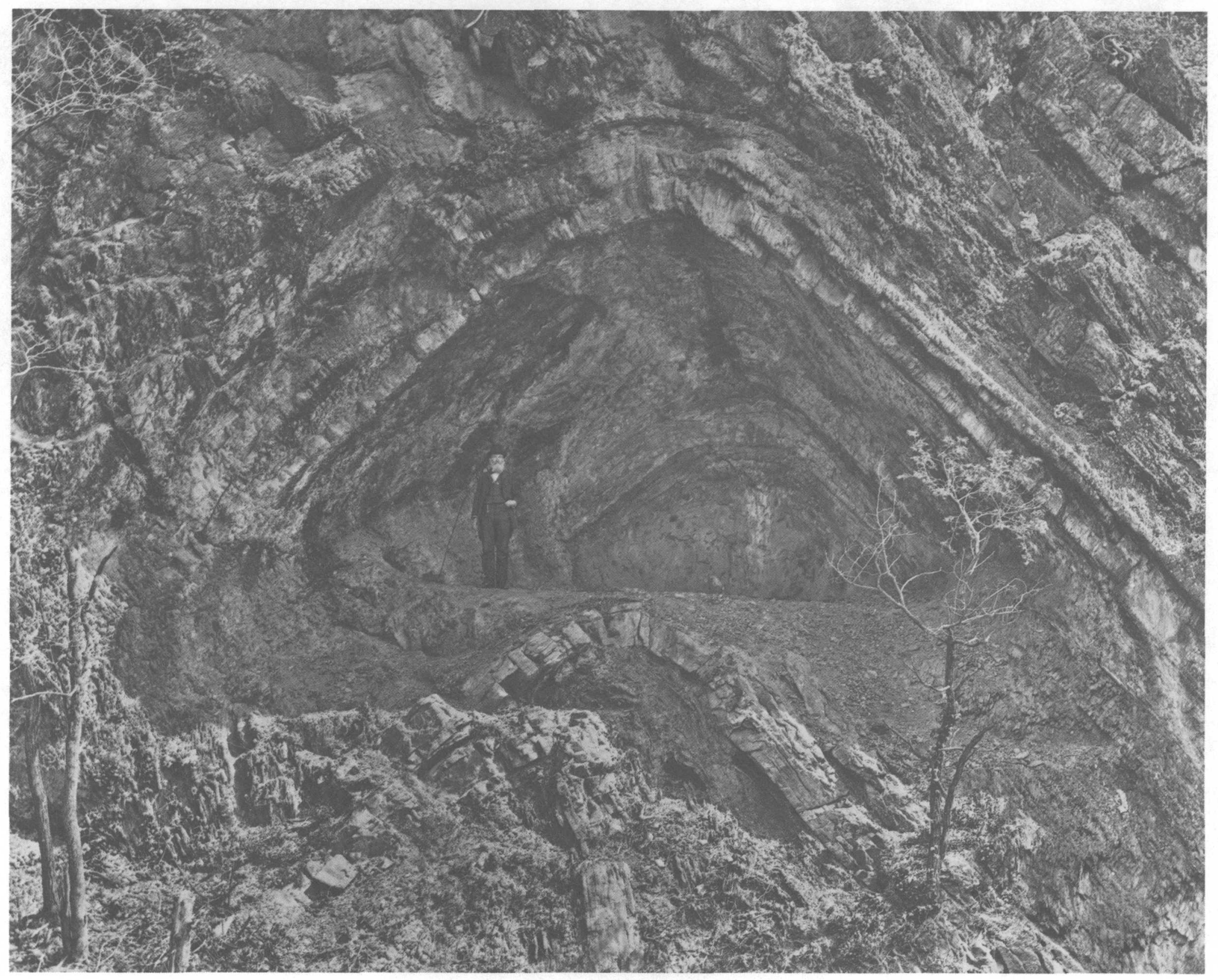


...... and laboratory investigations attempted to duplicate geologic processes to gain a better understanding of their nature.

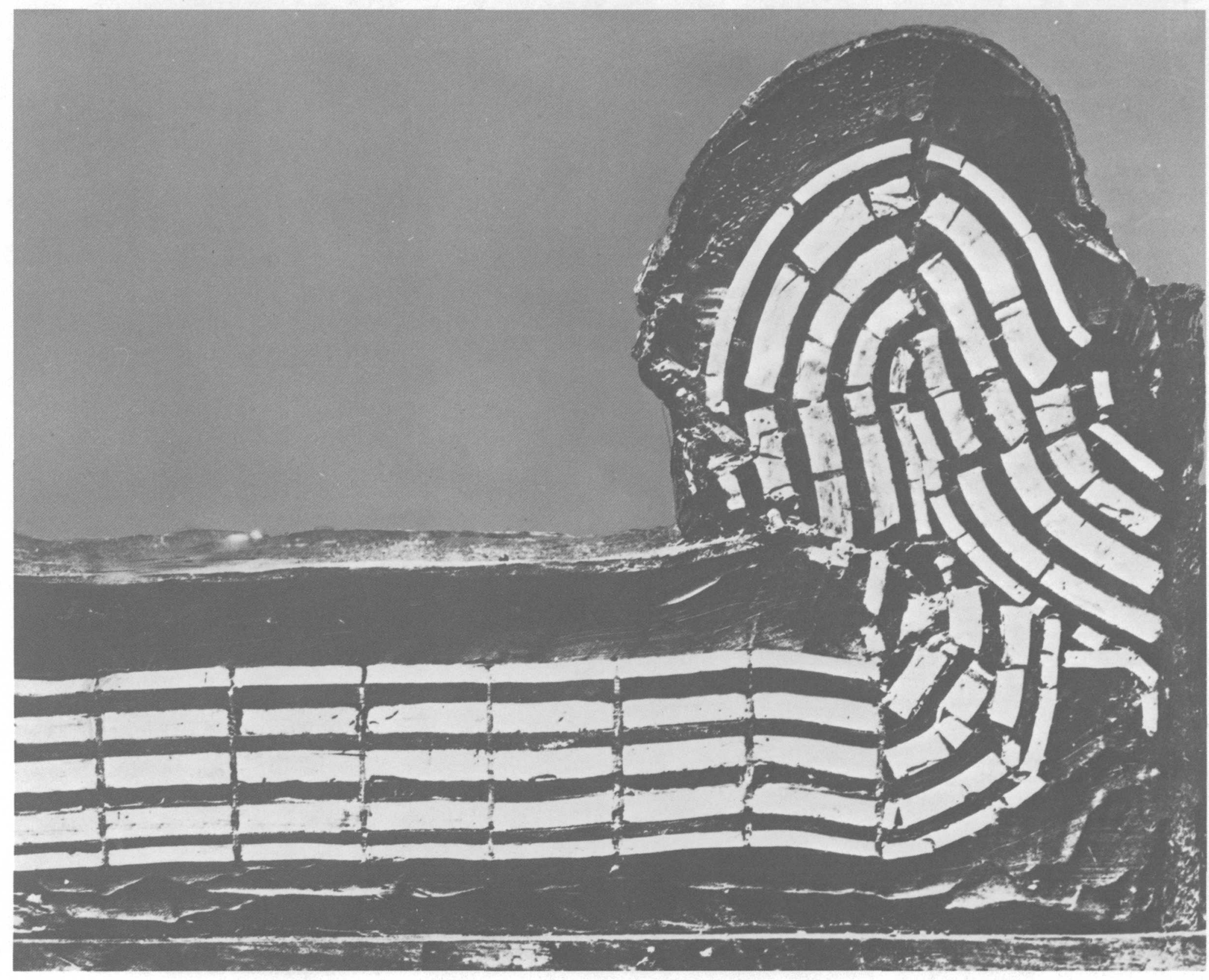



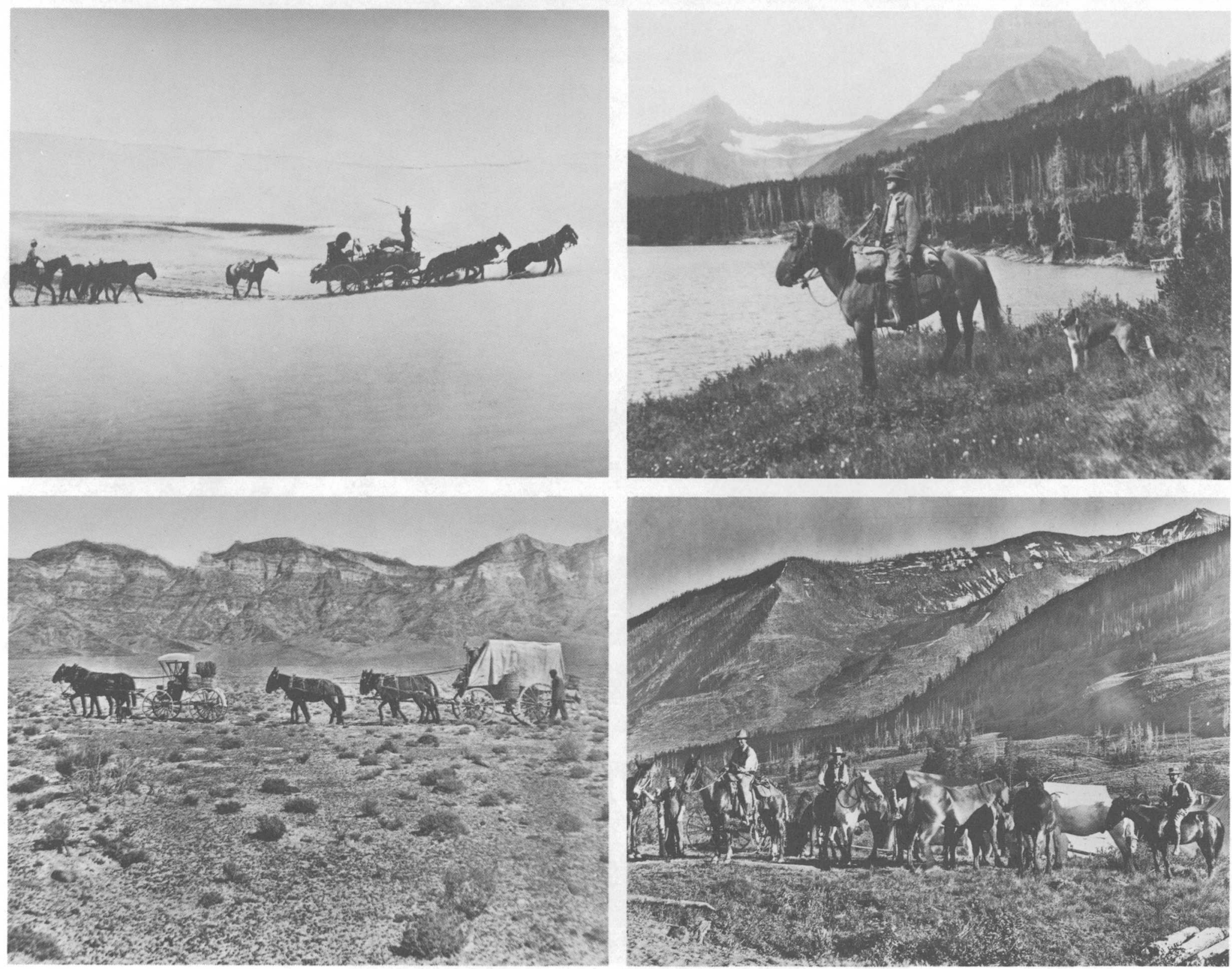

Geologists conducted fieldwork, using the best available transport. 
Under C. D. Walcott, the third Director, the agency expanded and diversified its activities as it coupled basic and applied studies in support of the mining industry and agriculture. An investigation of the downstream effects of placer mining on farming is an early example of the Geological Survey's concern about the impact of people's activities on their environment.

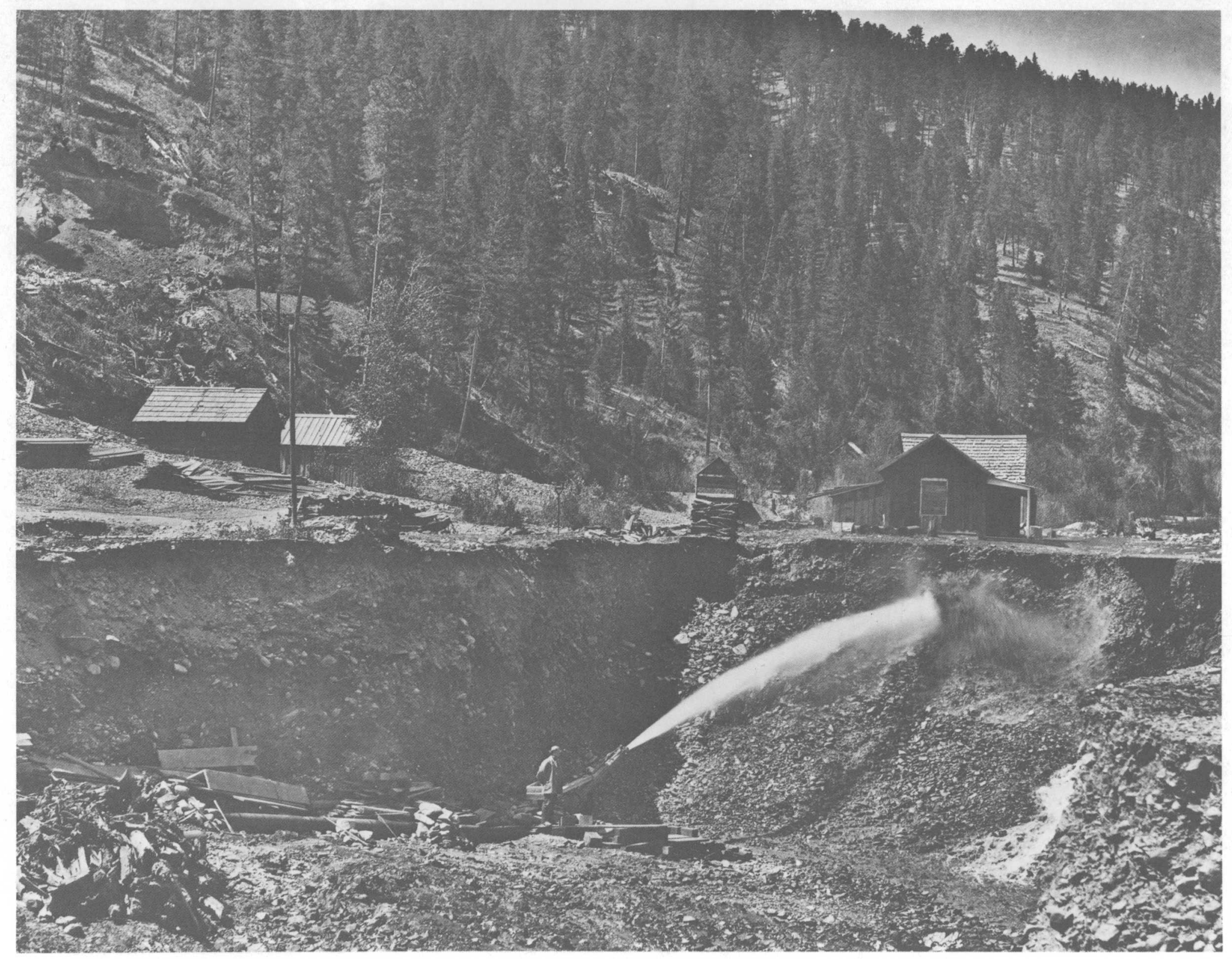


Studies of ice-age phenomena, especially in the Great Lakes States, continued the agency's investigations of environments and climates of geologically recent times.
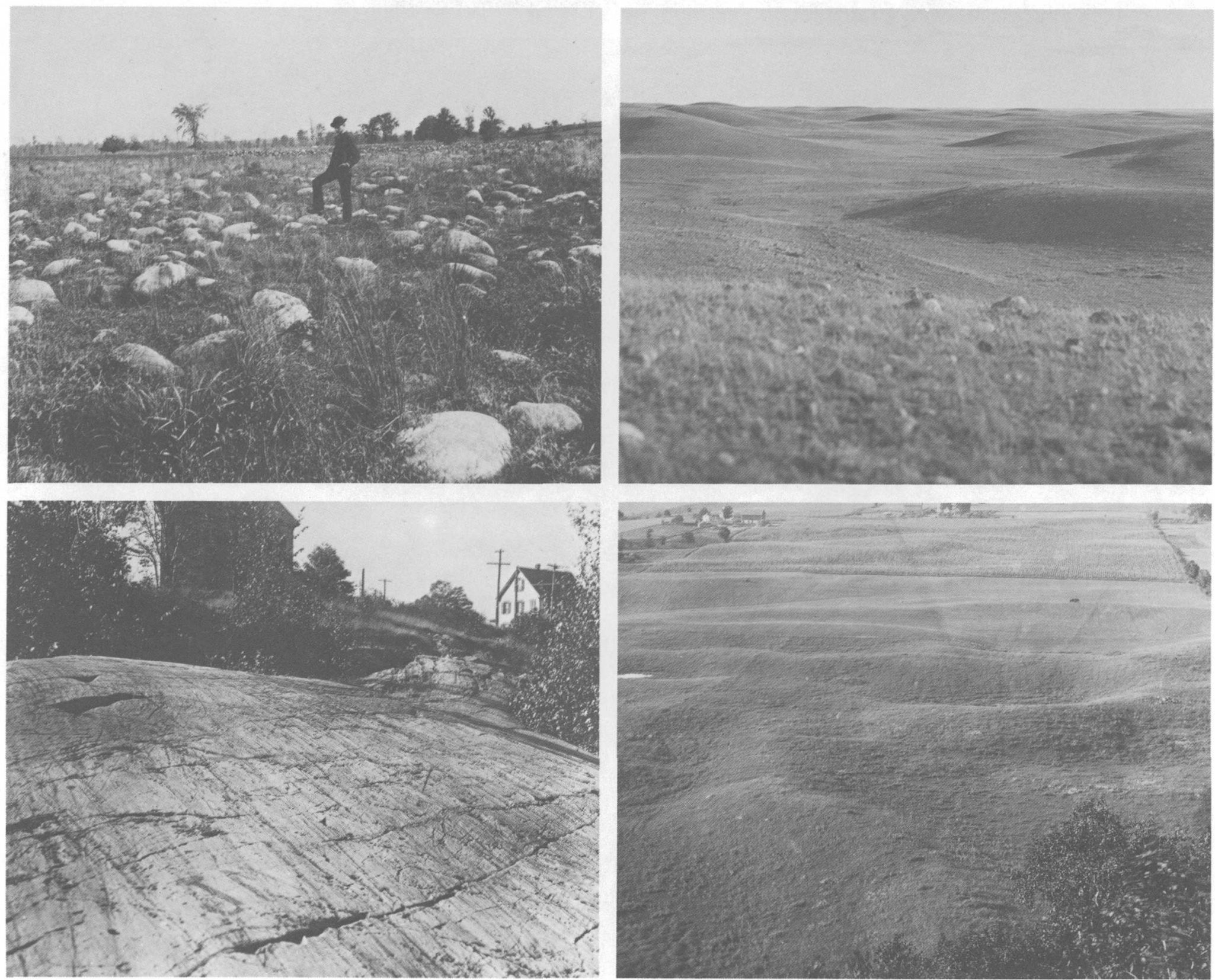
Fossil plants and animals became important tools for establishing the geologic age of rocks and correlating them from one region to another.

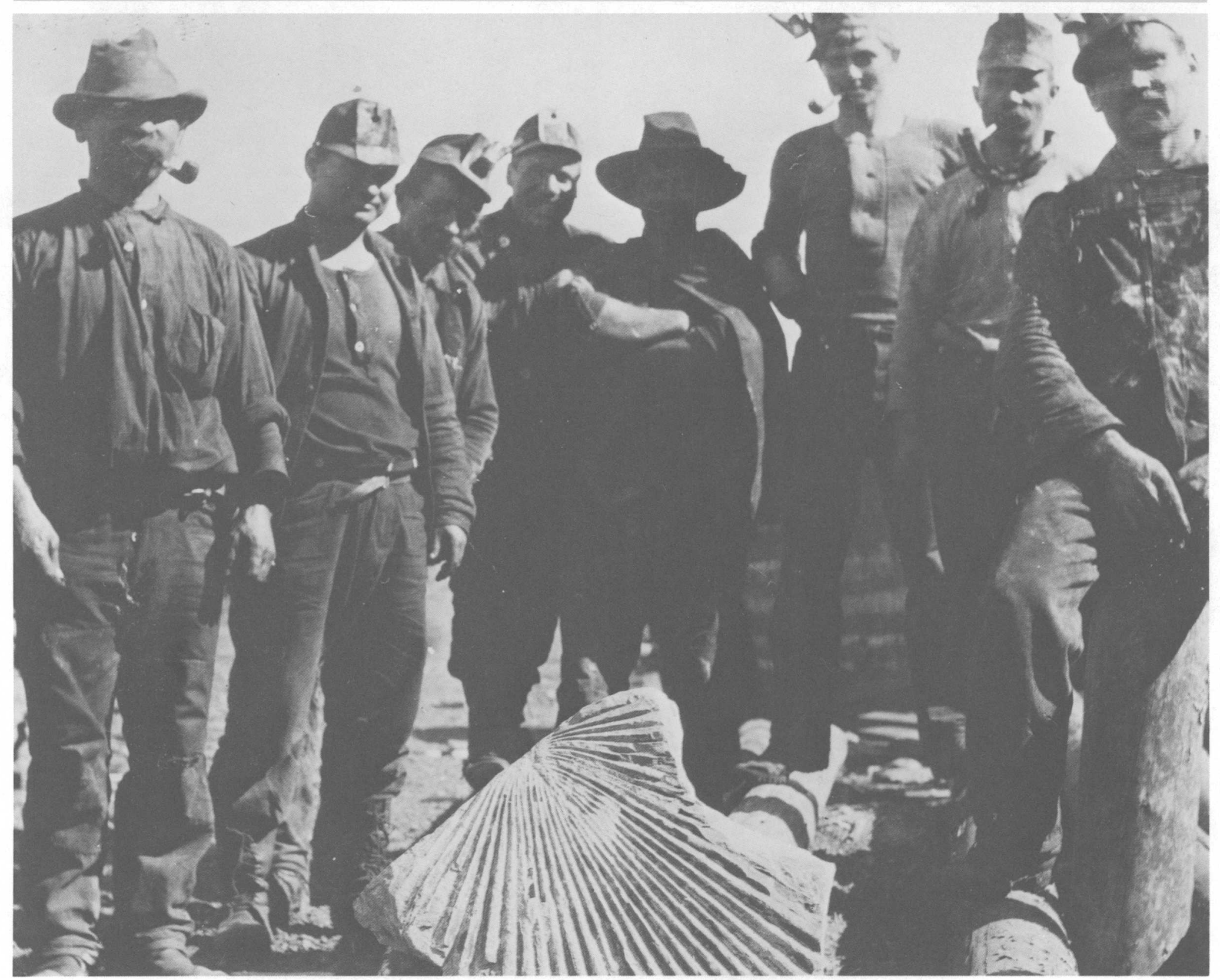




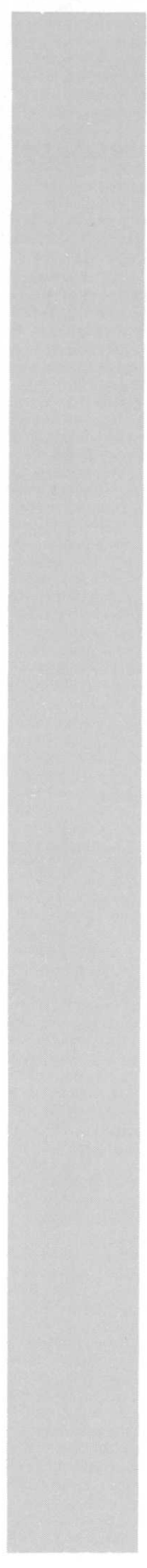

The Survey was closely associated with the conservation movement during Theodore Roosevelt's era and investigated and surveyed newly established national forests.
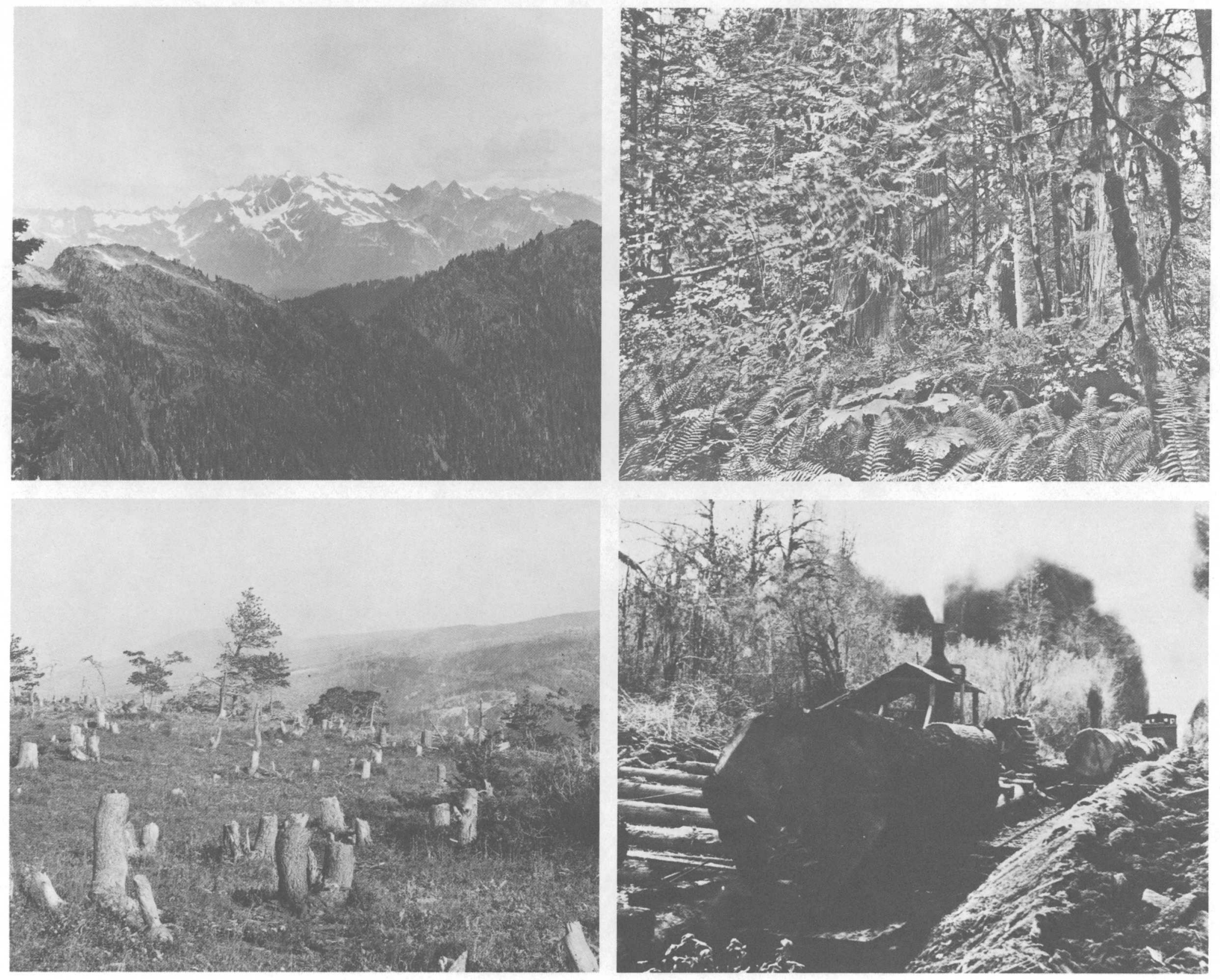

and national forest reserves 
At the turn of the century, in order to establish precisely our northern border, Geological Survey specialists joined our Canadian neighbors in a survey undertaken under the auspices of the Boundary Commission.

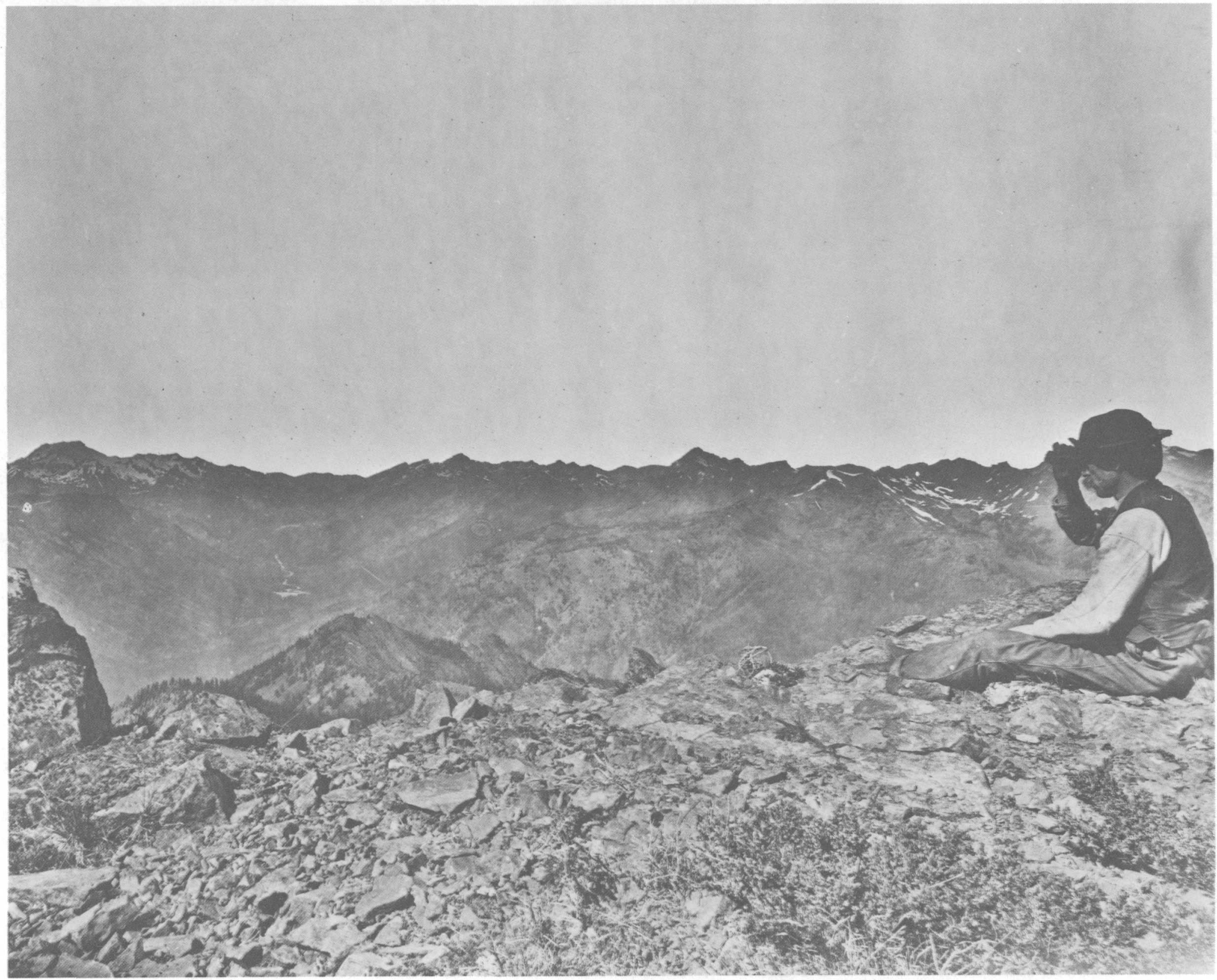




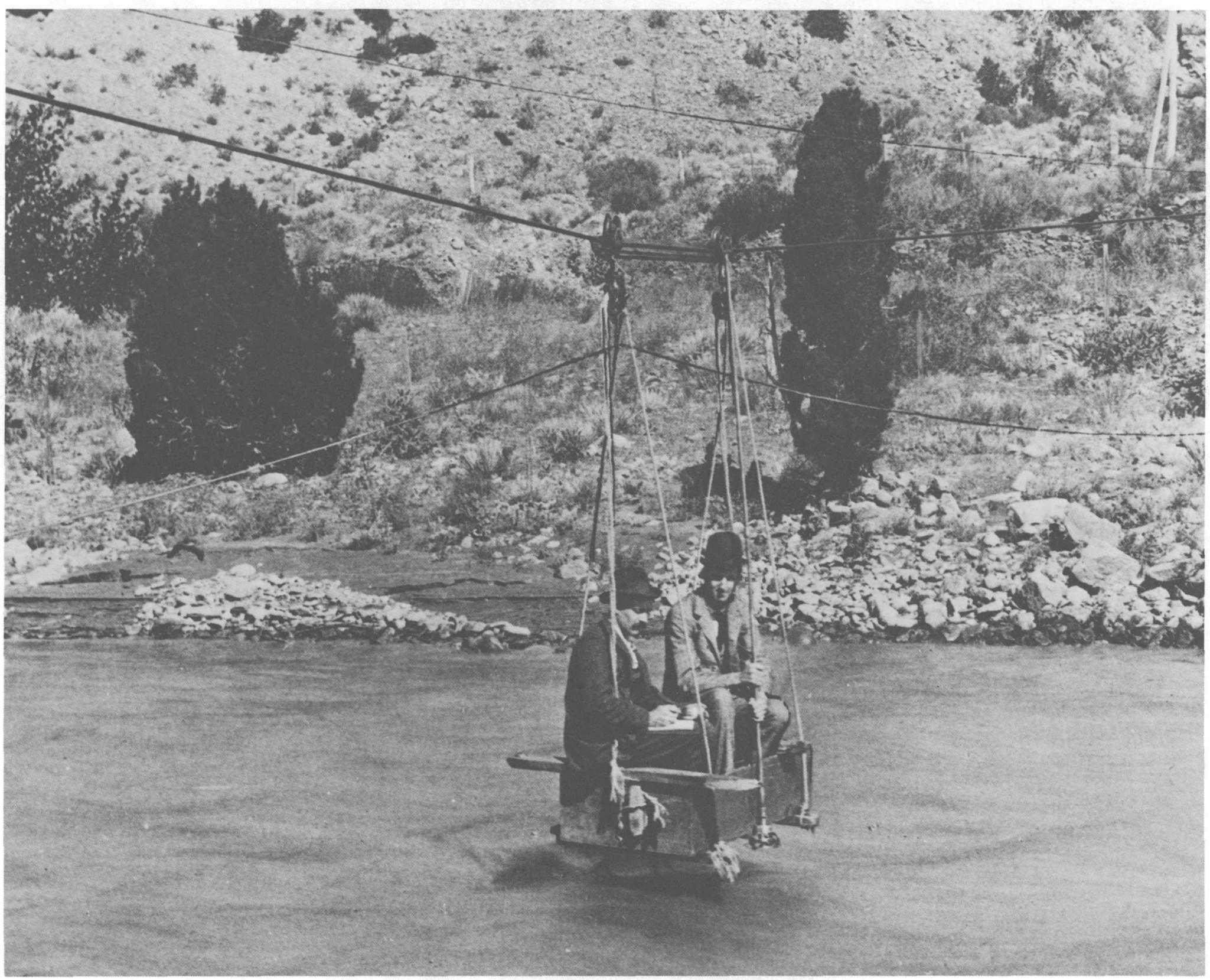




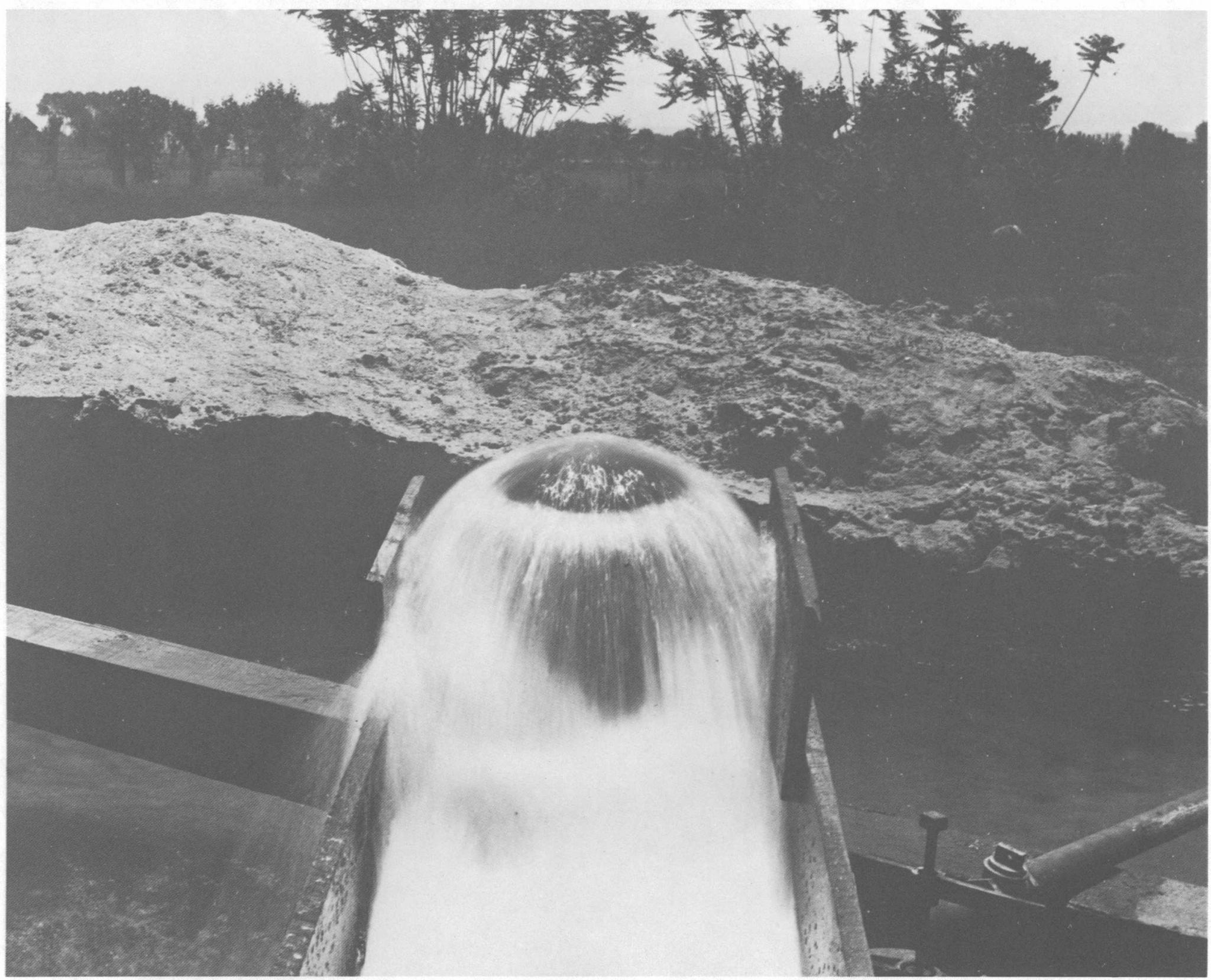




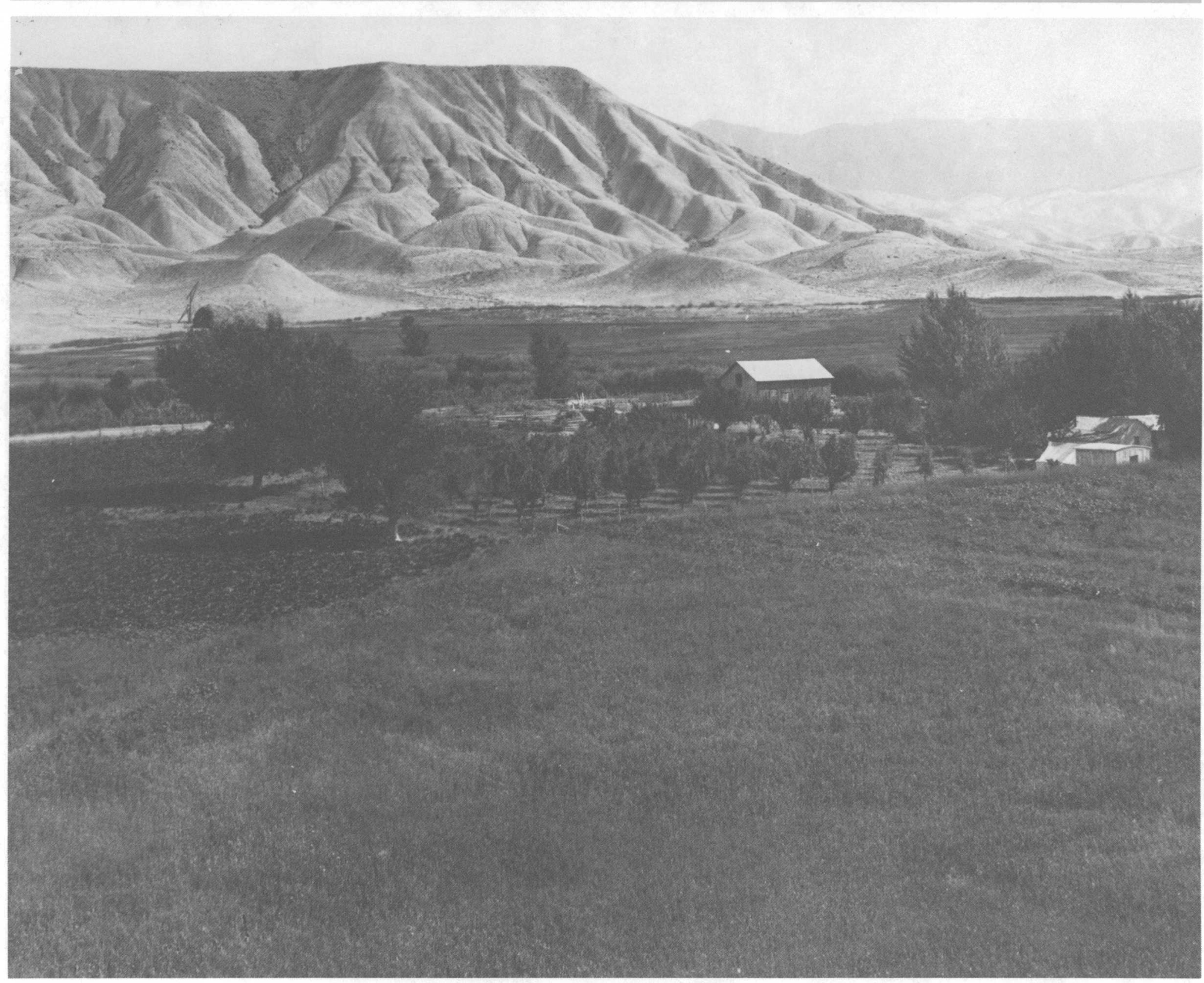


During the monetary crisis of the 1890's, the Nation and the Geological Survey became interested in the mineral resources (especially gold) of Alaska; even today, work in the North commands a significant part of the Survey's effort through its Alaskan Geology and other branches.
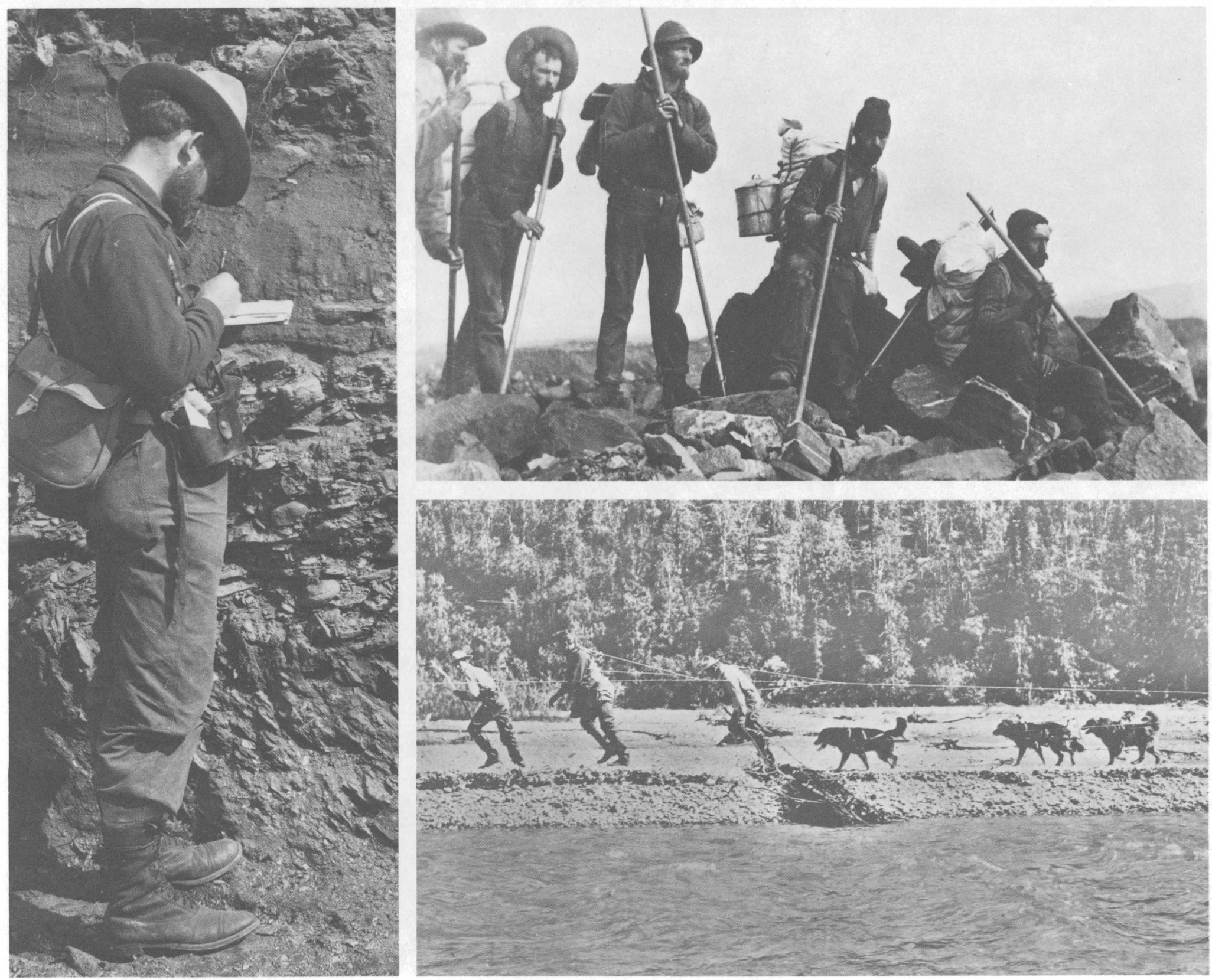

The Survey looked toward Alaska before the turn of the century. 

industries. In 1910, the Survey's Technologic Branch became the nucleus of the new Bureau of Mines.

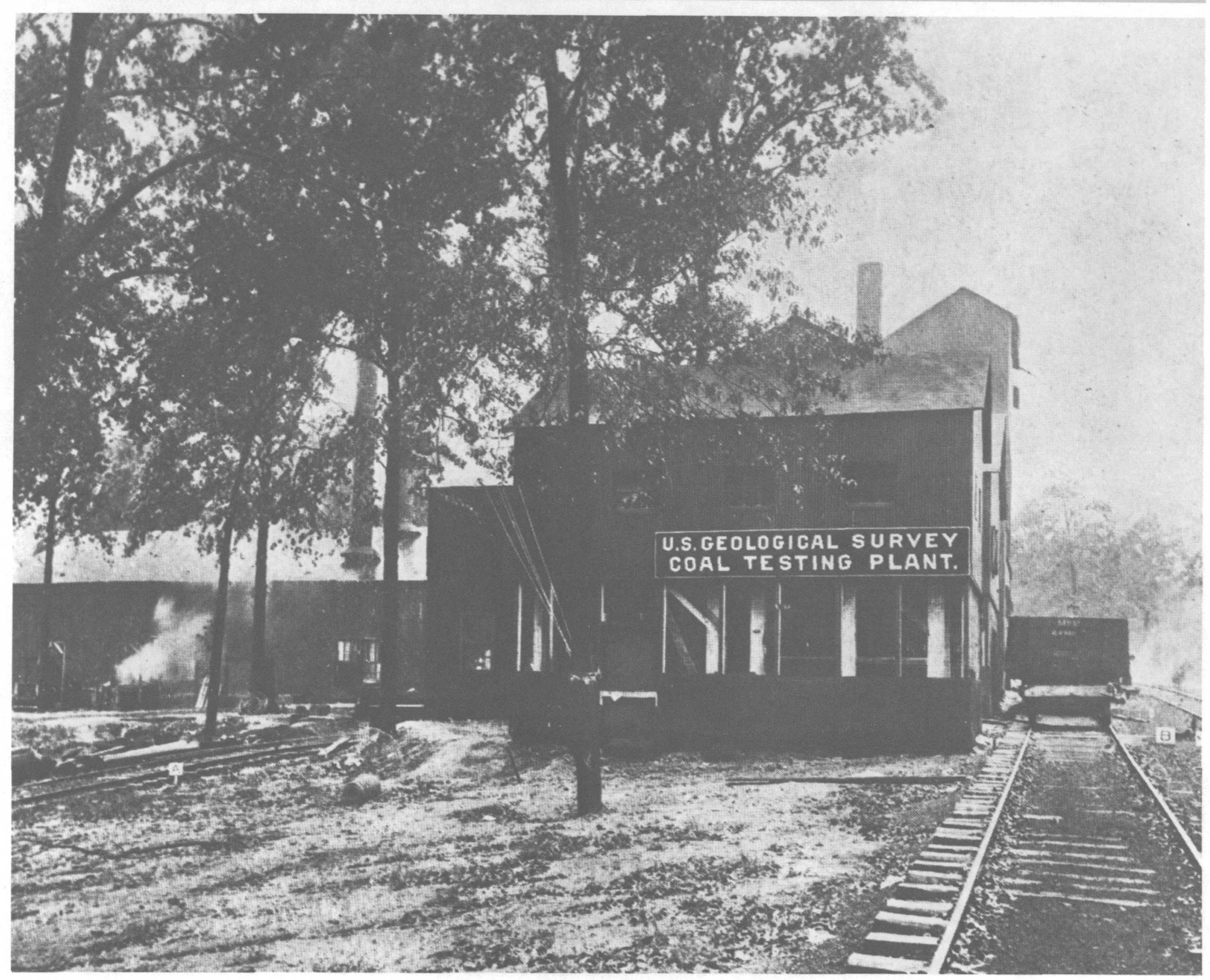


During World War I, the Topographic Branch mapped tactical and strategic areas in Europe and the United States, while the Geologic and Water Resources Branches worked to find badly needed strategic minerals, fuels, and water supplies at home.

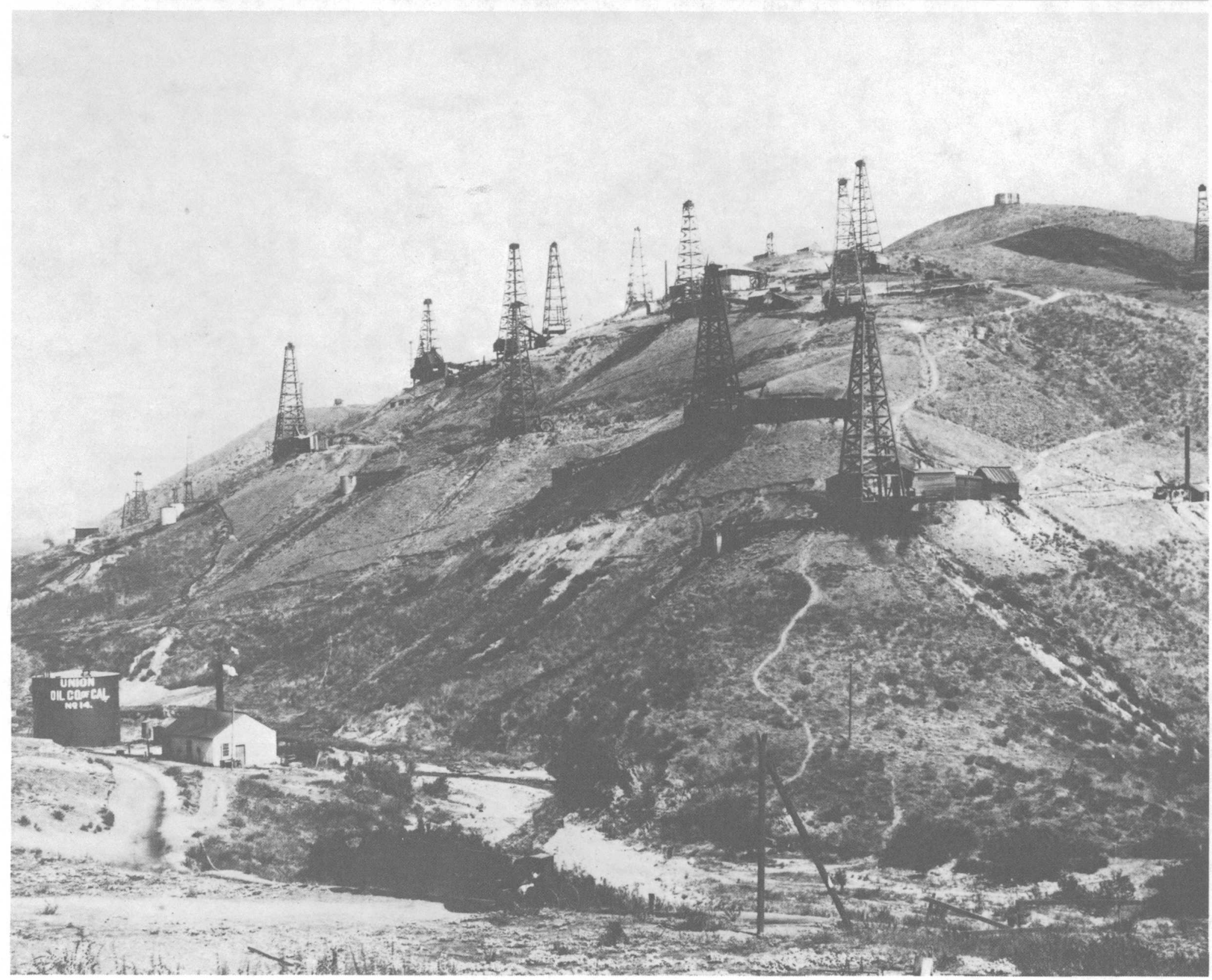


The fourth Director, G. O. Smith, emphasized classification of the public lands and their resources, including oil shale; this work led to the formation of the Survey's Land Classification Board, established in 1908. It became a branch in 1912 and was renamed the Conservation Branch in 1925 when the supervision of mineral leases was delegated to the Survey.
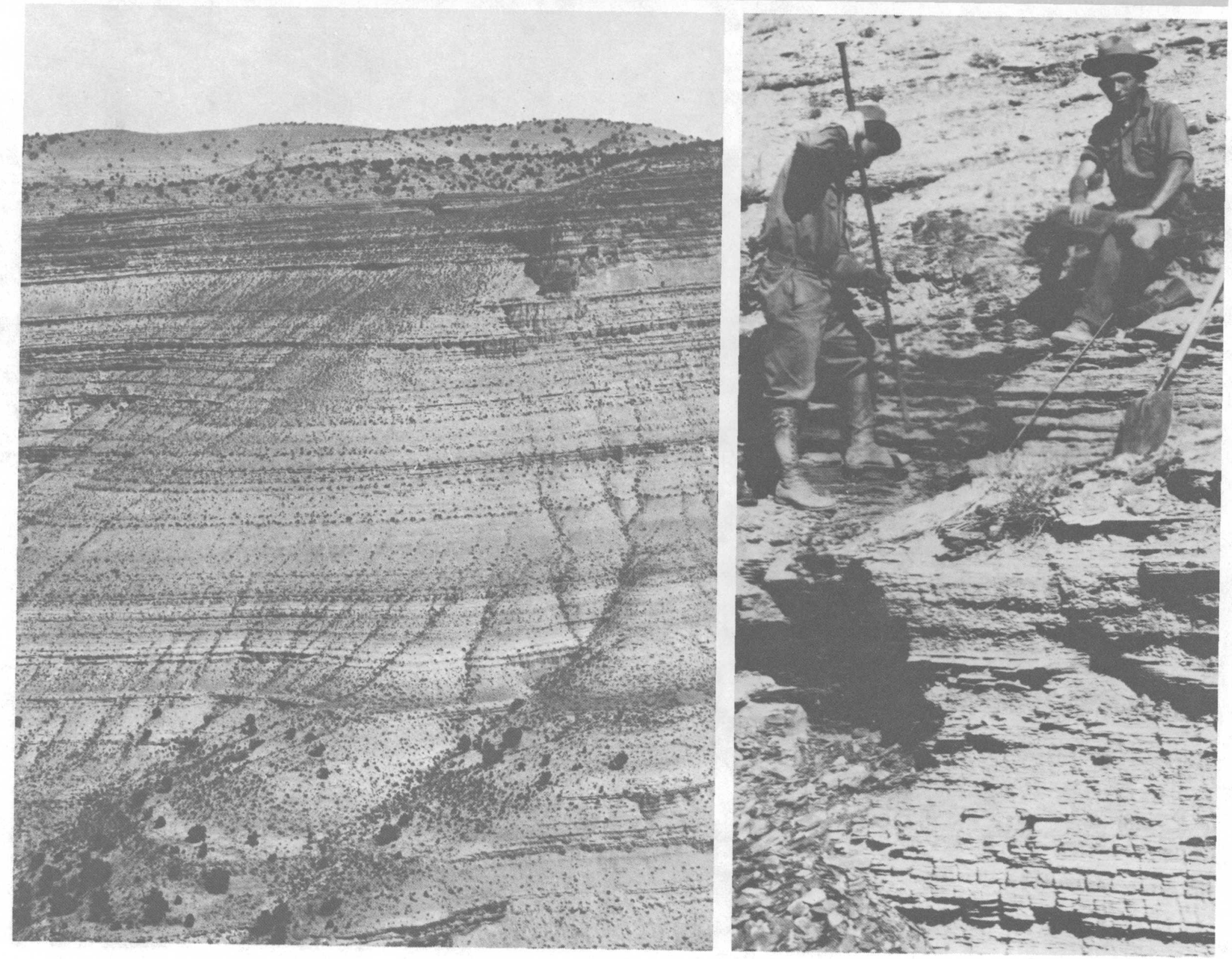

Work on oil shales began in the 1910's. 
The expenses of field work gradually increased and the automobile replaced the horse.
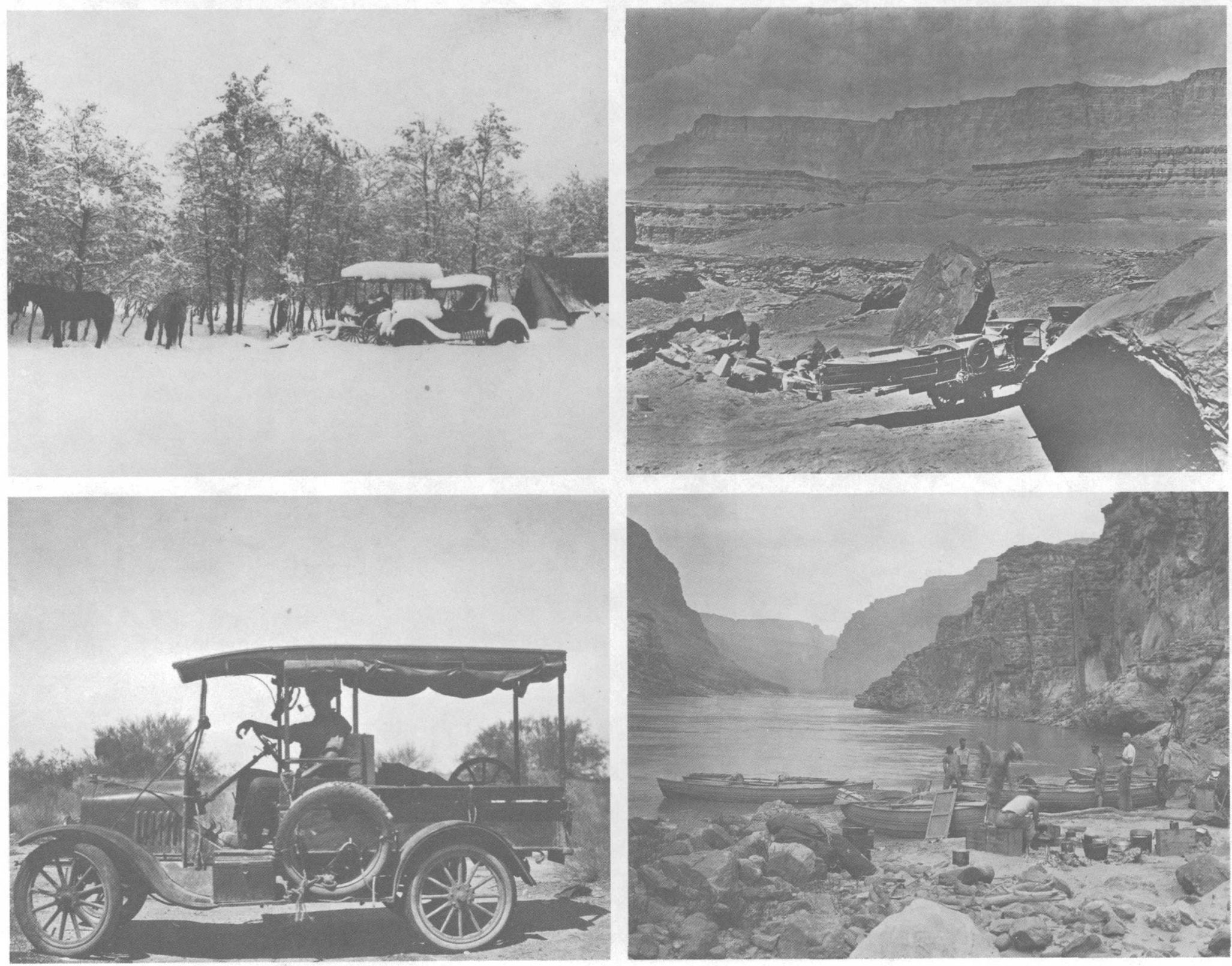

Transport improved, even in the Grand Canyon 


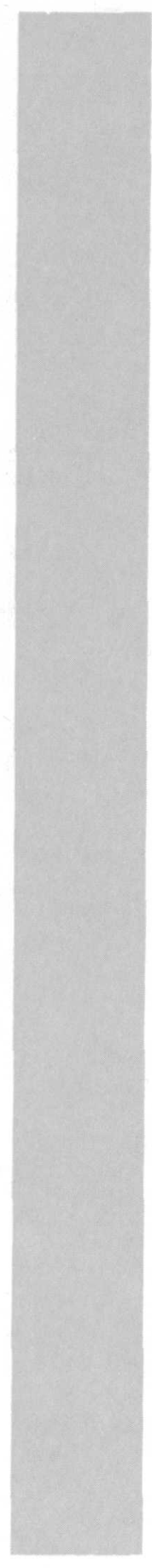

Accounts had always been kept carefully, but under the eminently practical Smith, the Survey's administrative staff kept a watchful eye on all activities.

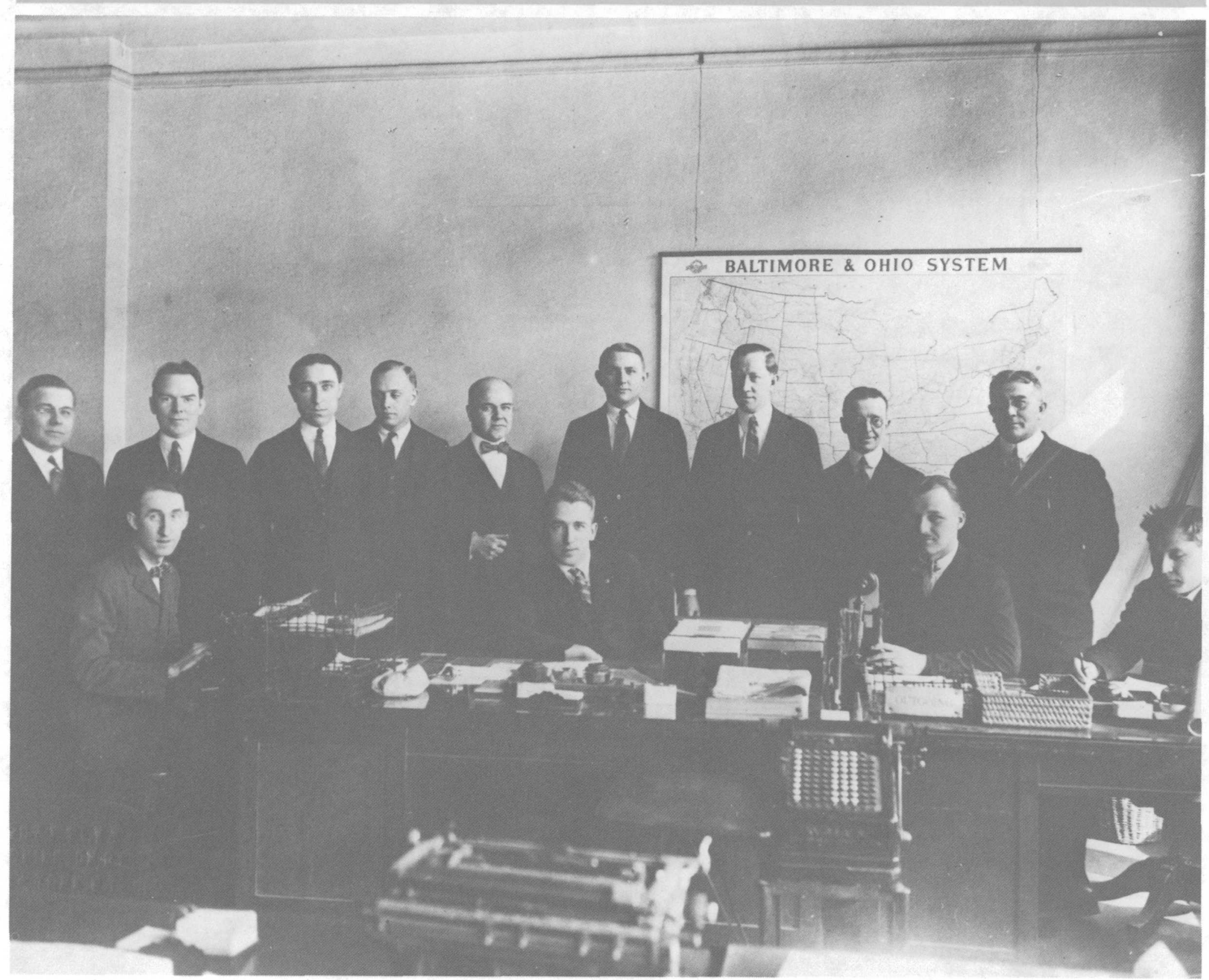


The Depression of the 1930's caused a reduction in the activities of many Federal bureaus, but despite this, W. C. Mendenhall, the fifth Director, reemphasized the importance of basic research, and the Geological Survey took initial steps toward more sophisticated methods of gathering data.

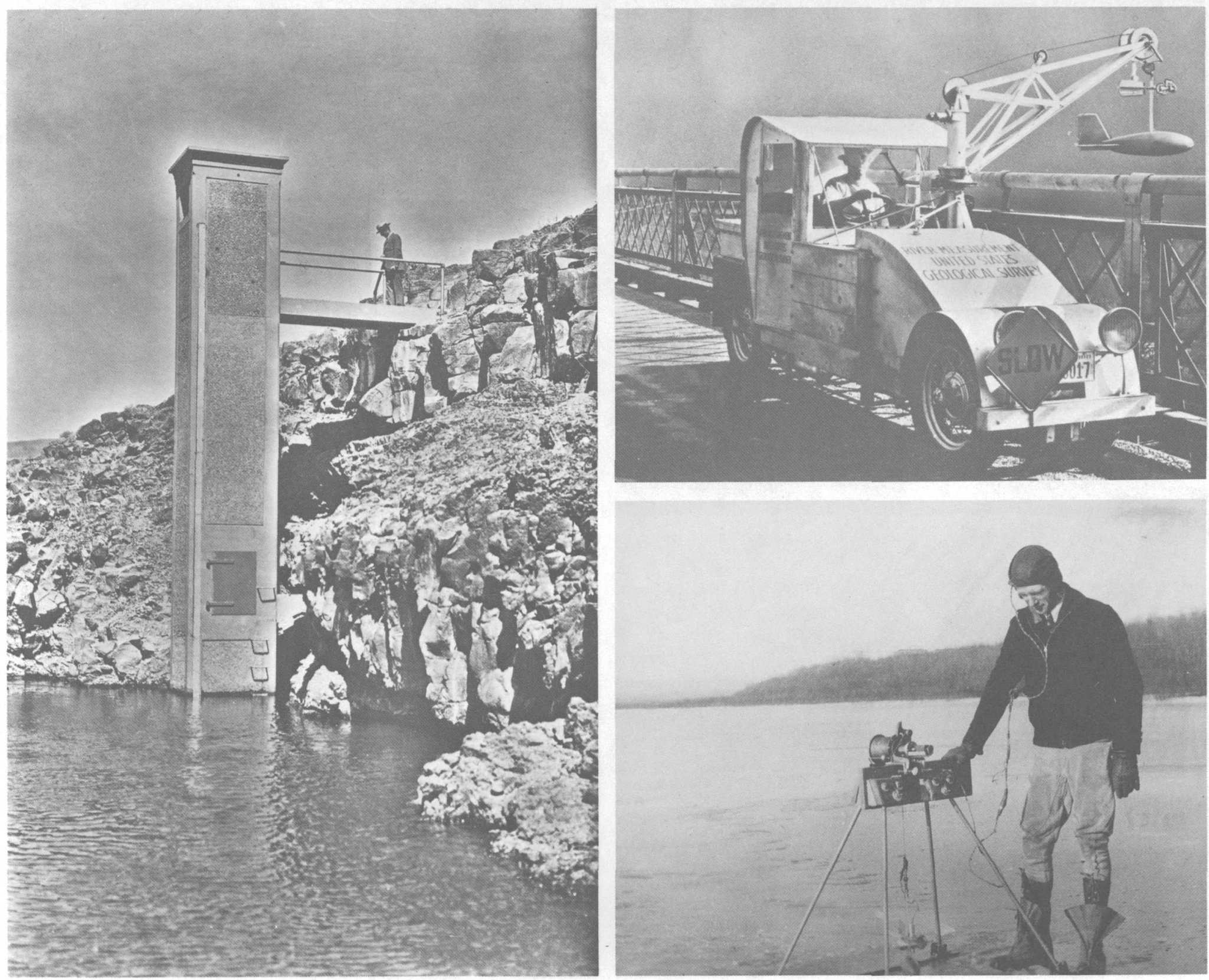


On the eve of World War II, the Survey responded once more to the Nation's need for strategic minerals and fuels. The Nation's total commitment to winning World War II led to the establishment of the Military Geology Branch, which supplied terrain analysis and other specialized intelligence services. W. E. Wrather, the sixth Director, provided leadership during the difficult war years. In the midst of postwar turmoil, the agency resumed some of its more traditional but equally vital duties.
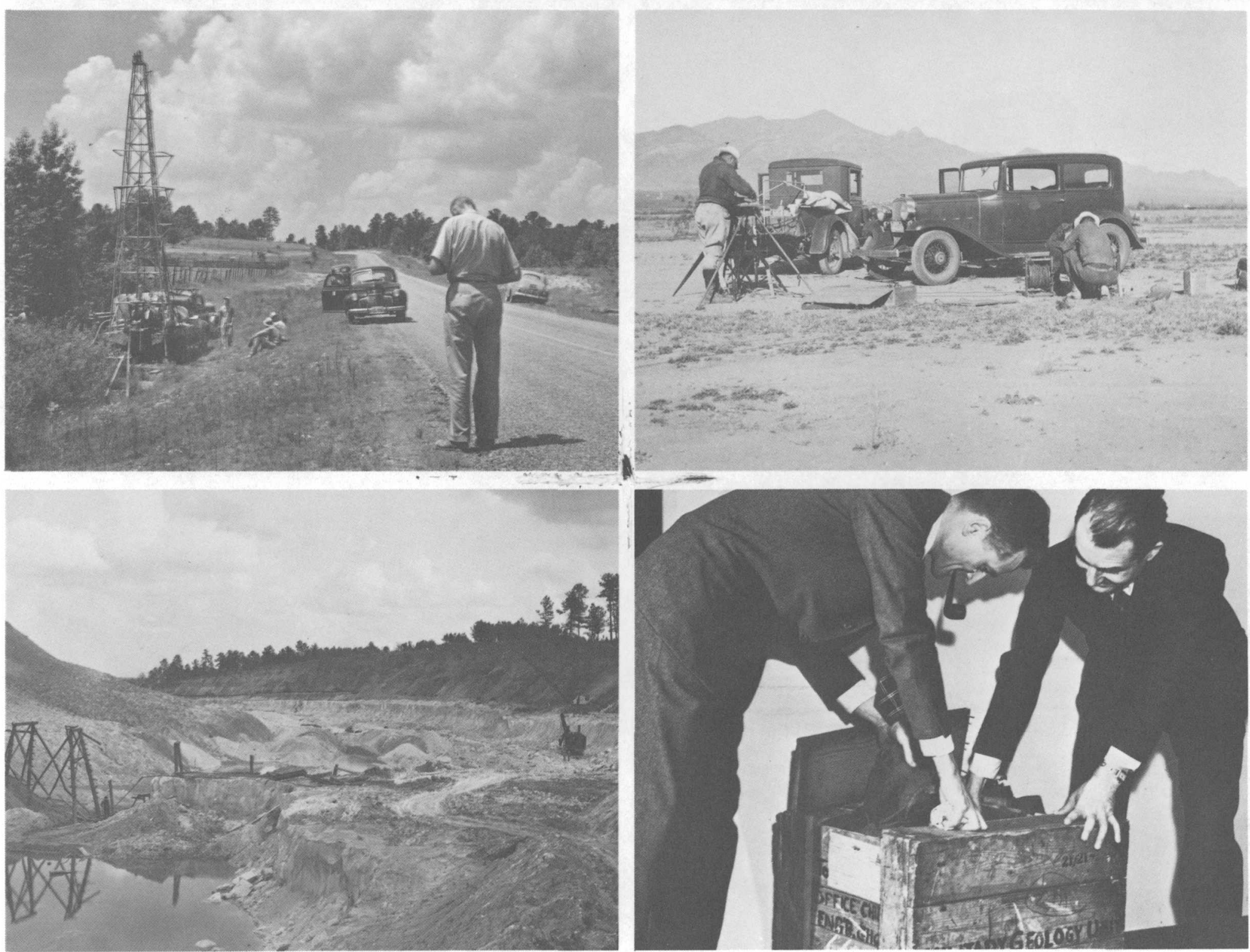
In the 1950's, the Geological Survey's research staff expanded under Wrather and T. B. Nolan (the Survey's first Assistant Director, who became the seventh Director in 1956), as a result of increased operational responsibilities, especially the exploration for uranium and other critical ores.

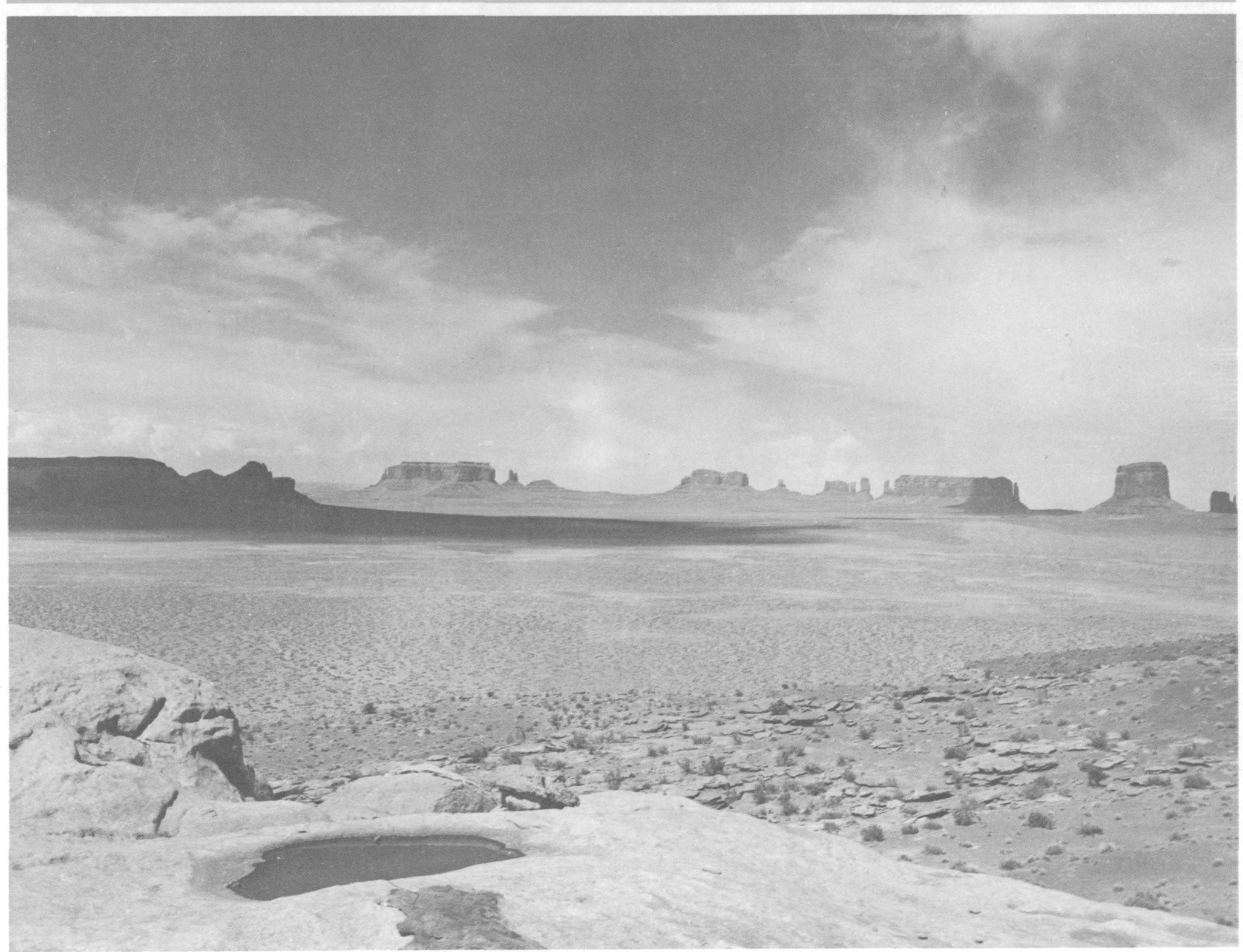

In the nuclear age, geologists returned to the Colorado Plateau to find uranium. 


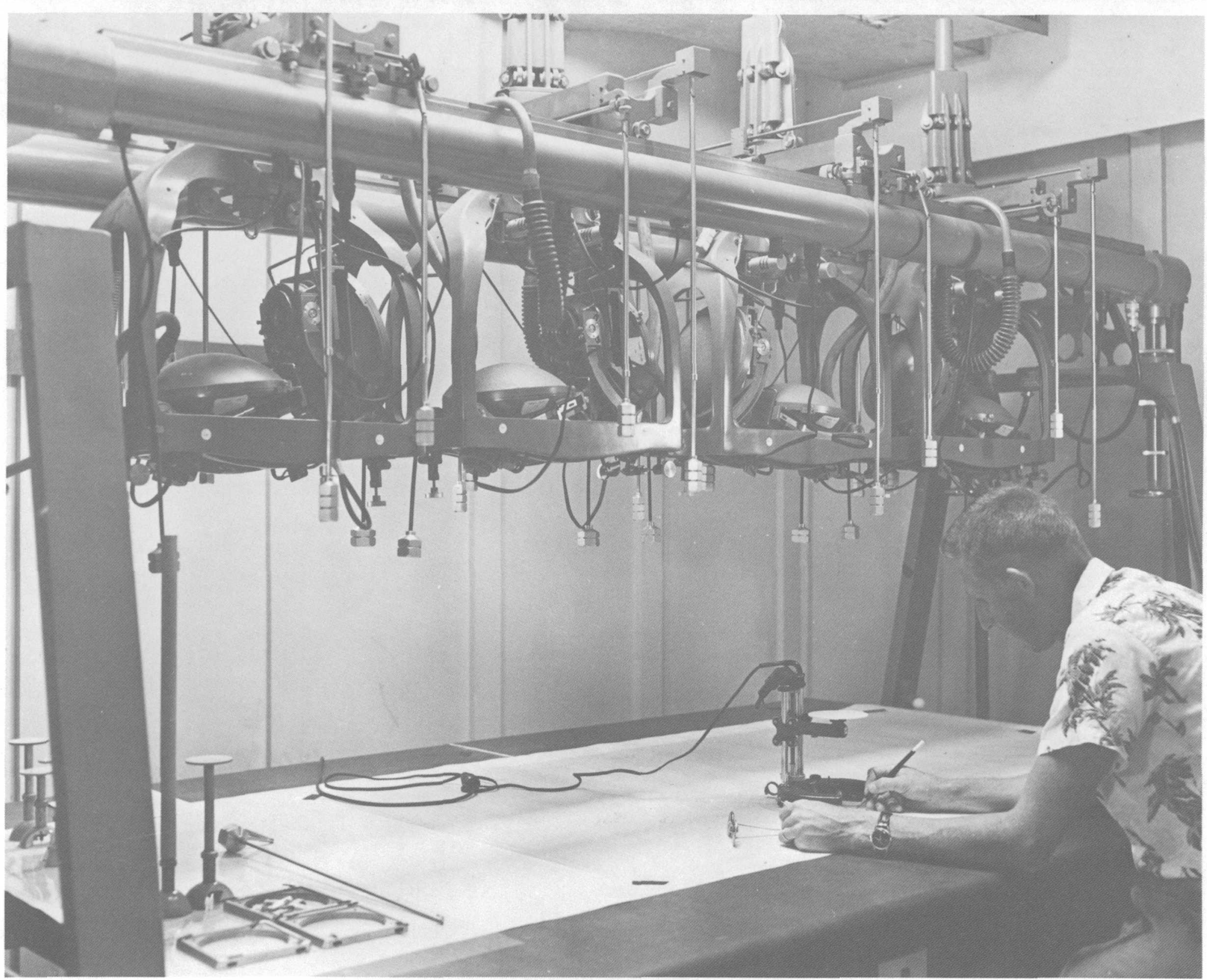


The Survey adapted wartime advances in electronics to peacetime uses in science, strengthened

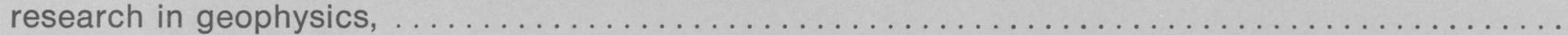
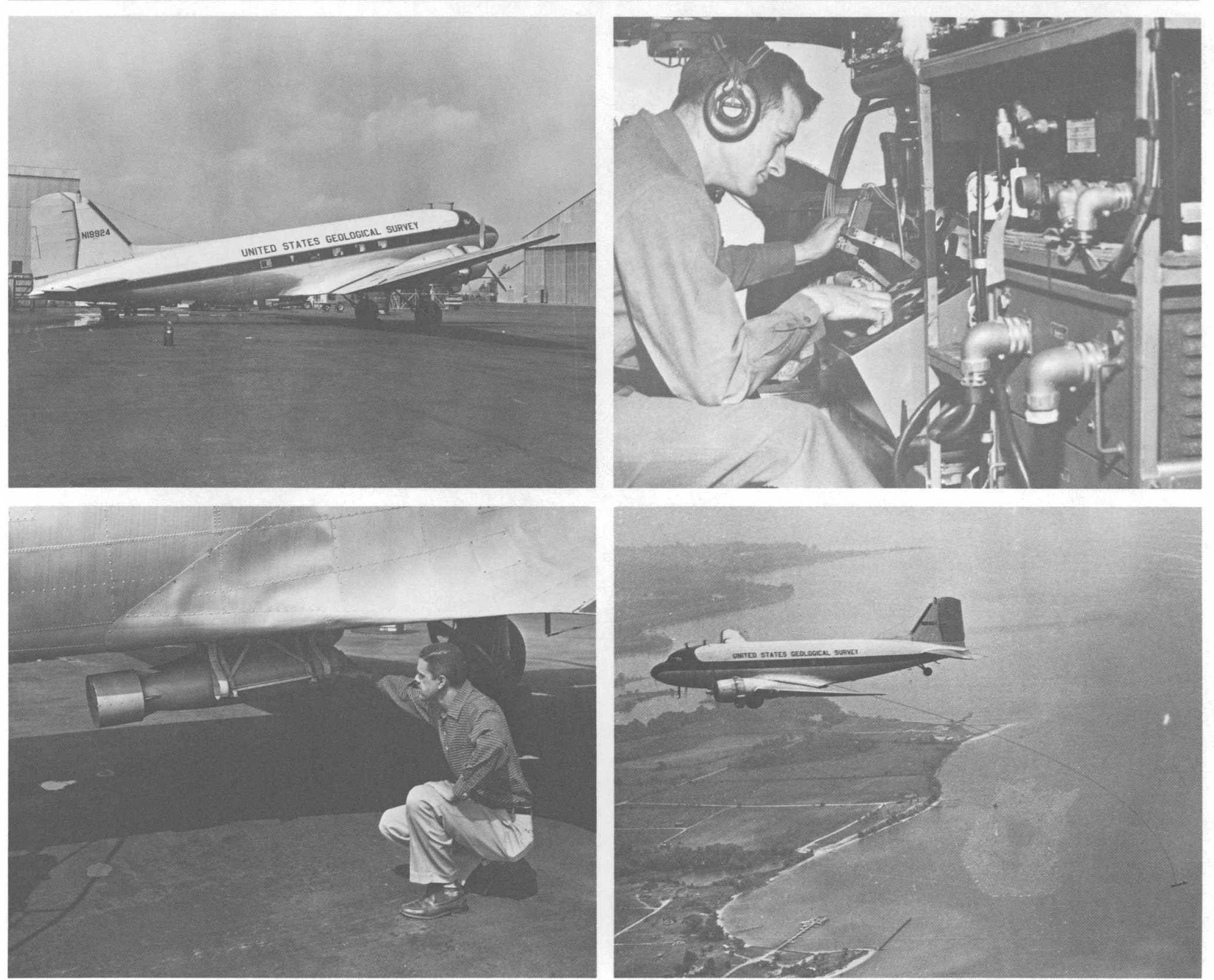

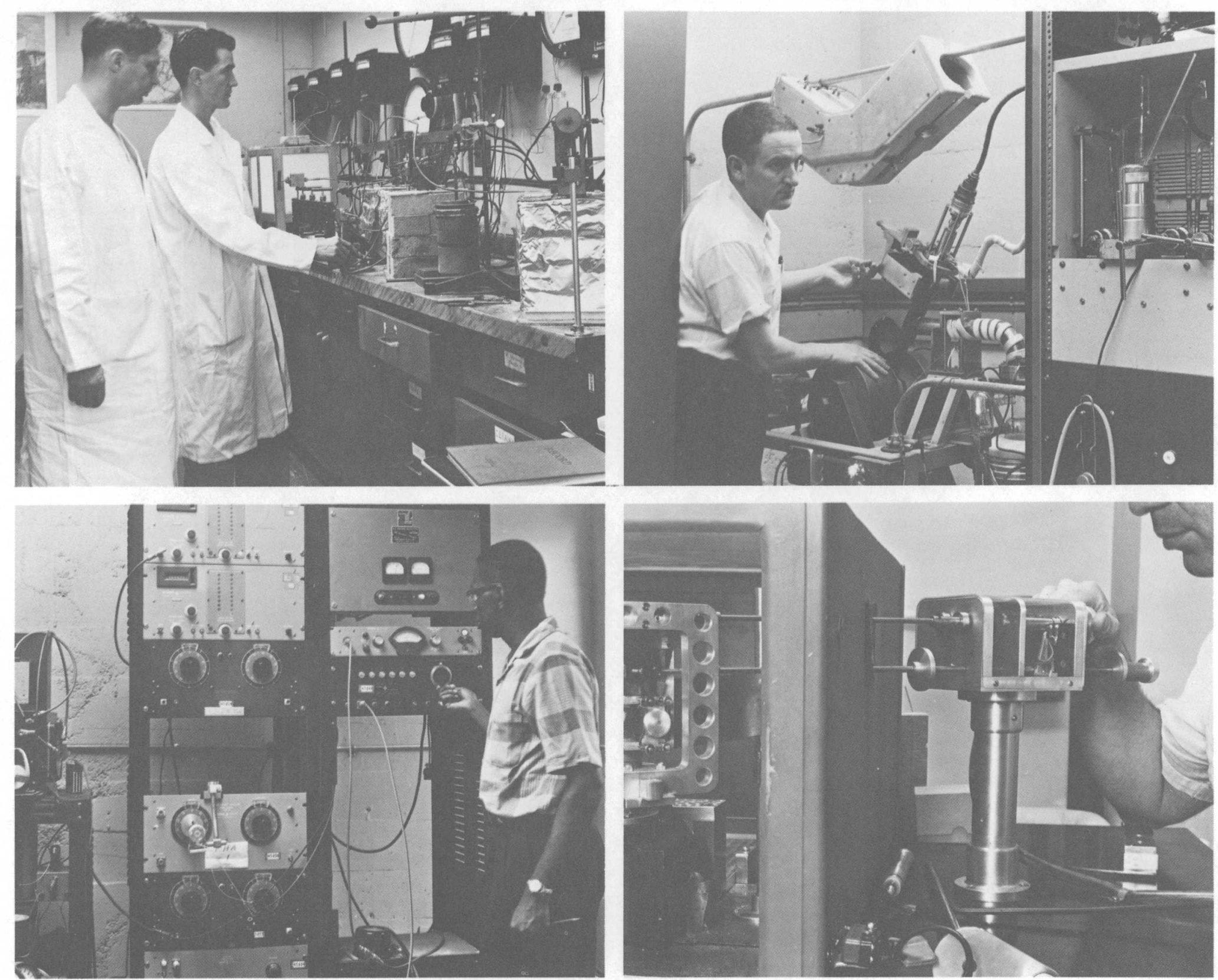

Laboratory studies became increasingly complex 
The Geological Survey has continued to emphasize the importance of field studies of geologic processes coupled with research in analytical techniques.

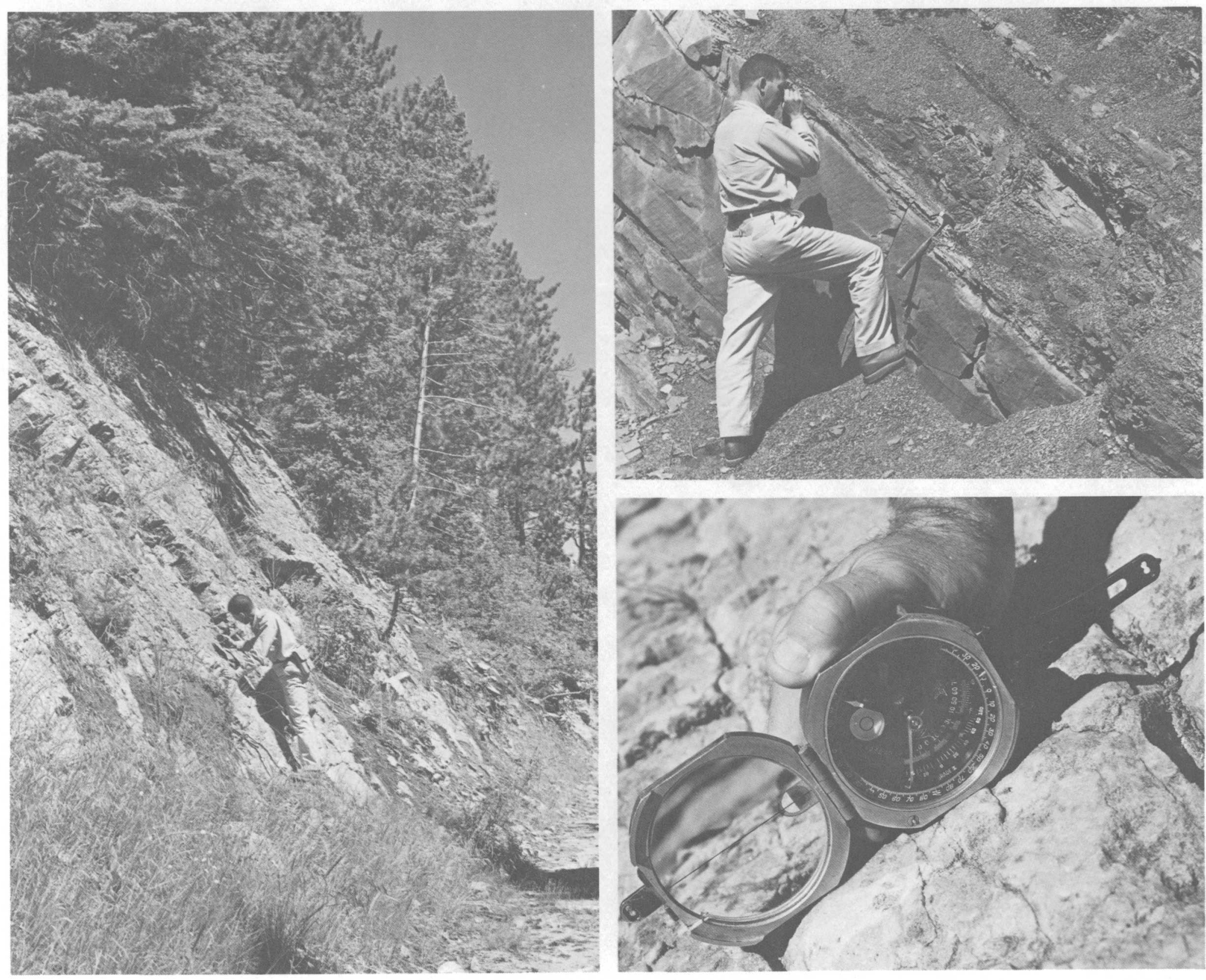


Studies at the Hawaiian Volcano Observatory typify this blend of basic field geology and modern analytical techniques.

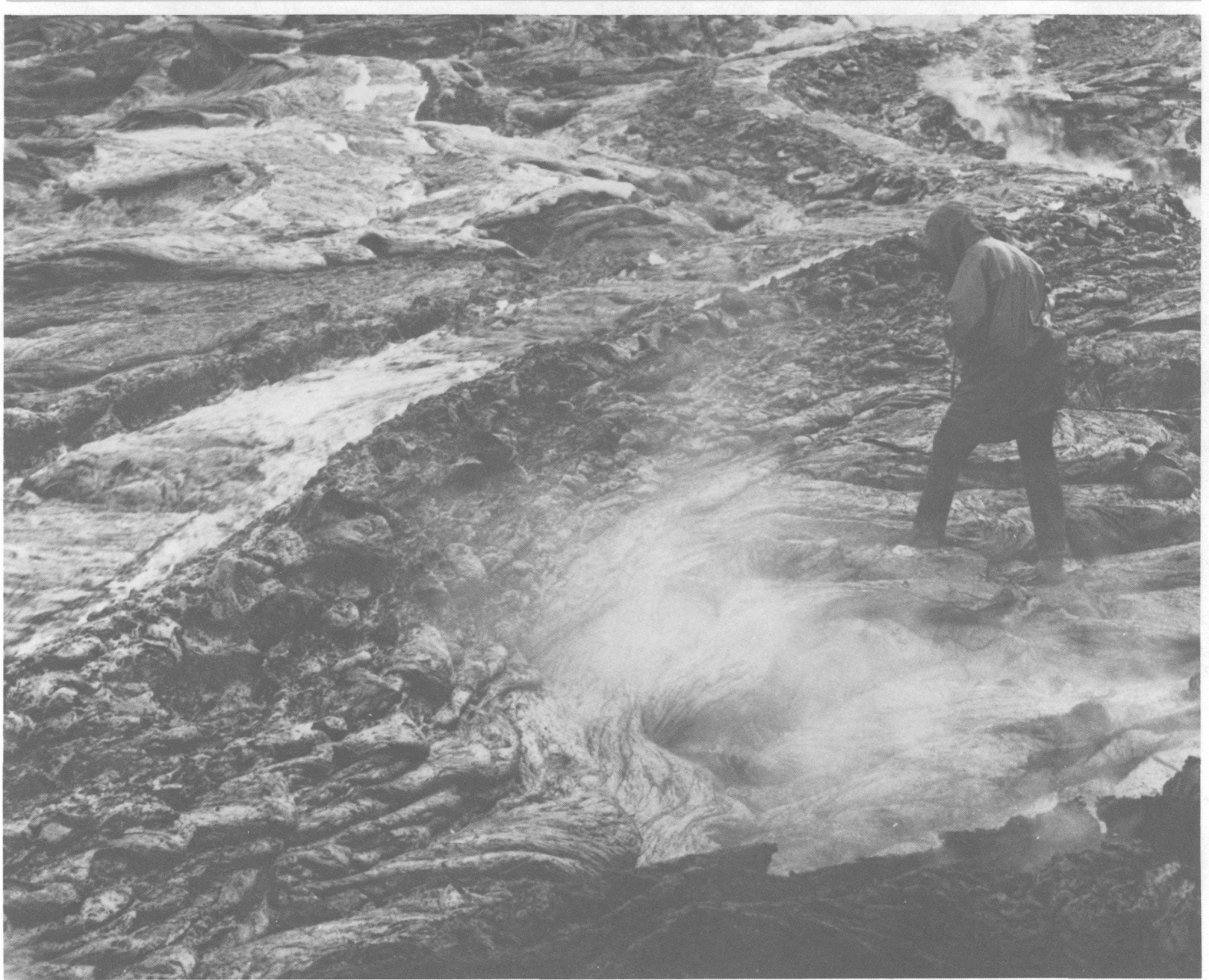


Along with new tools came new responsibilities in the Antarctic and other diverse locales.

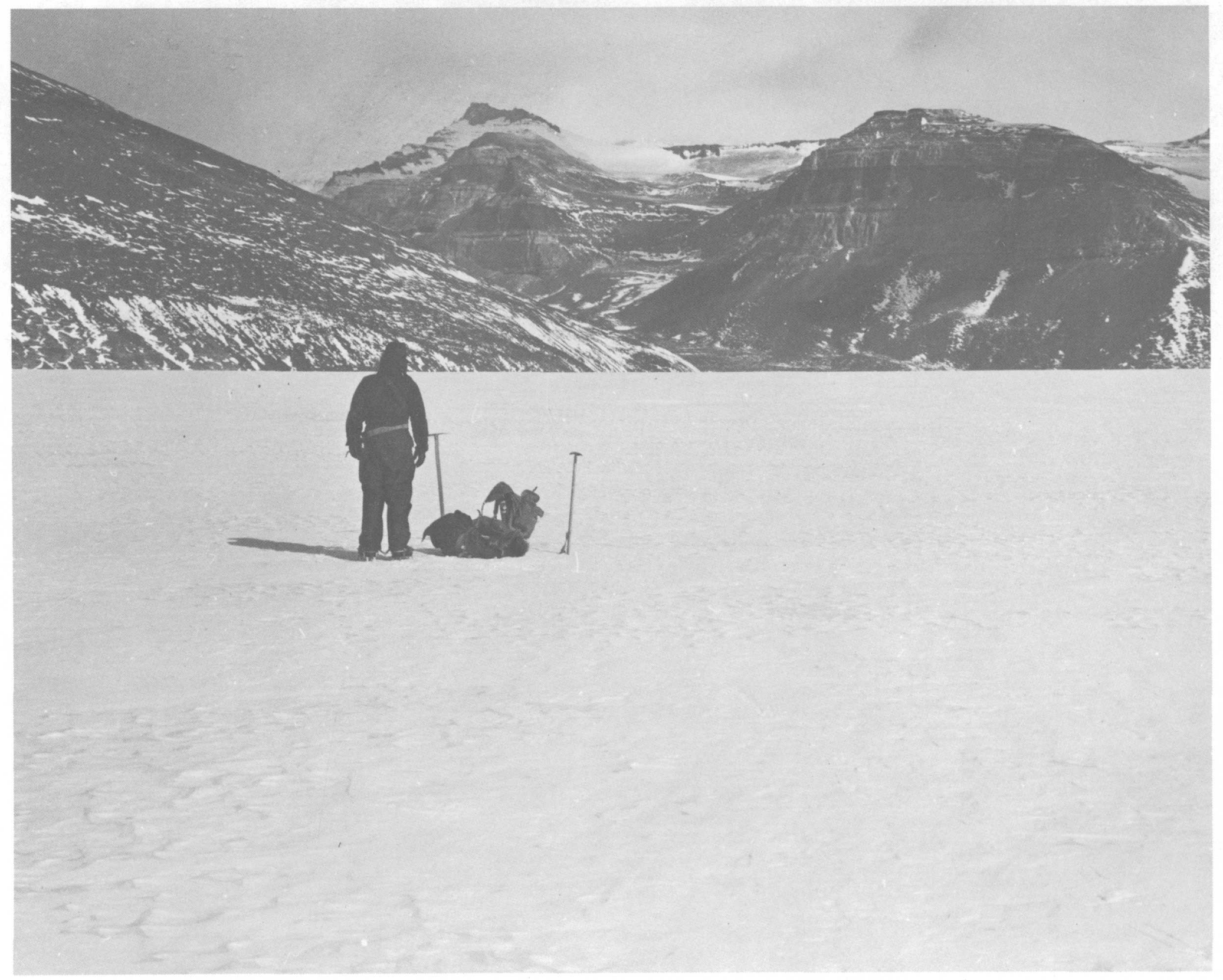


In 1962, Congress granted authority for work overseas, formalizing earlier wartime investigations in Central and South America and postwar studies of the Pacific islands.

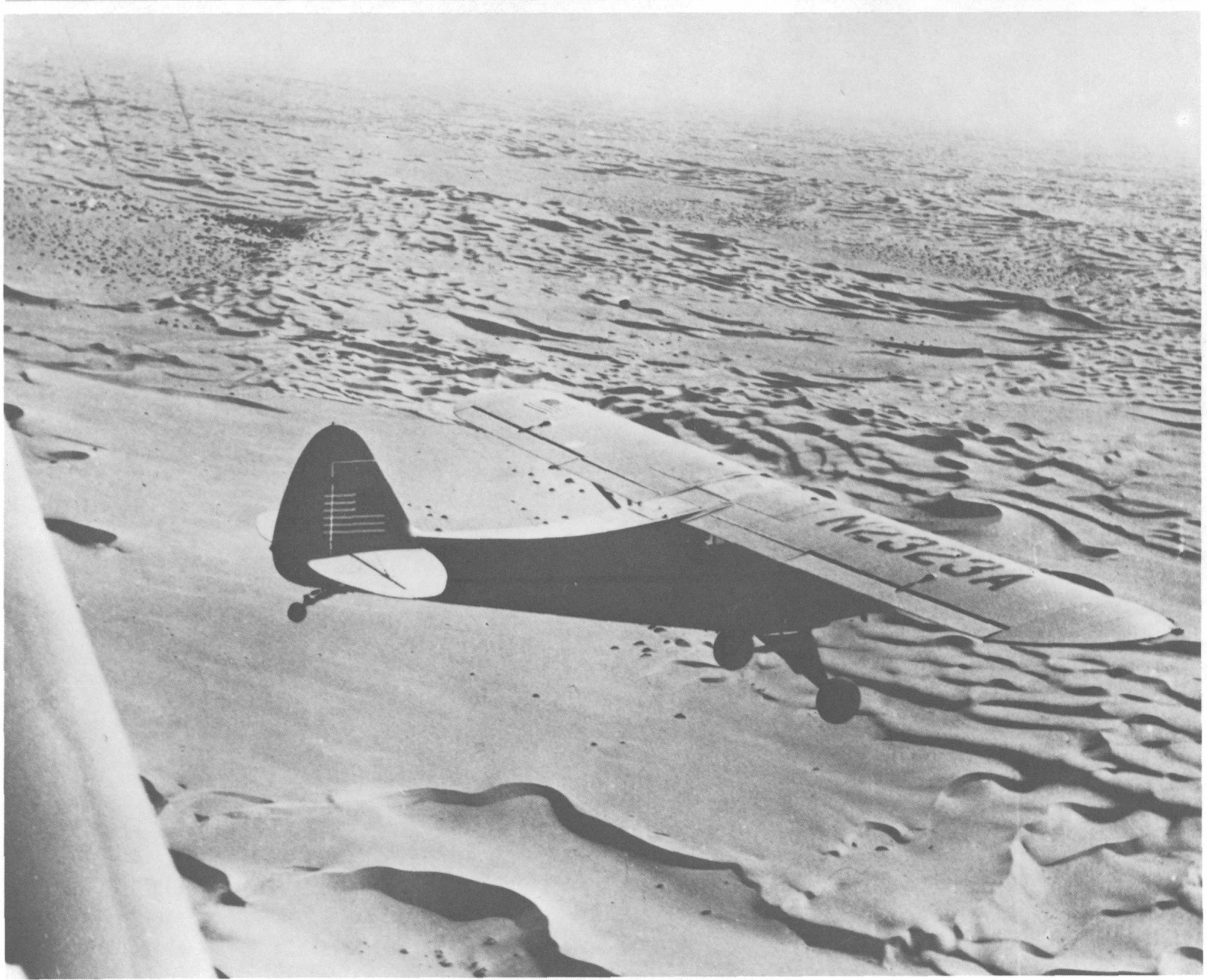


Agency specialists used their experience to assist other countries in their efforts to raise the standard of living of their citizens.
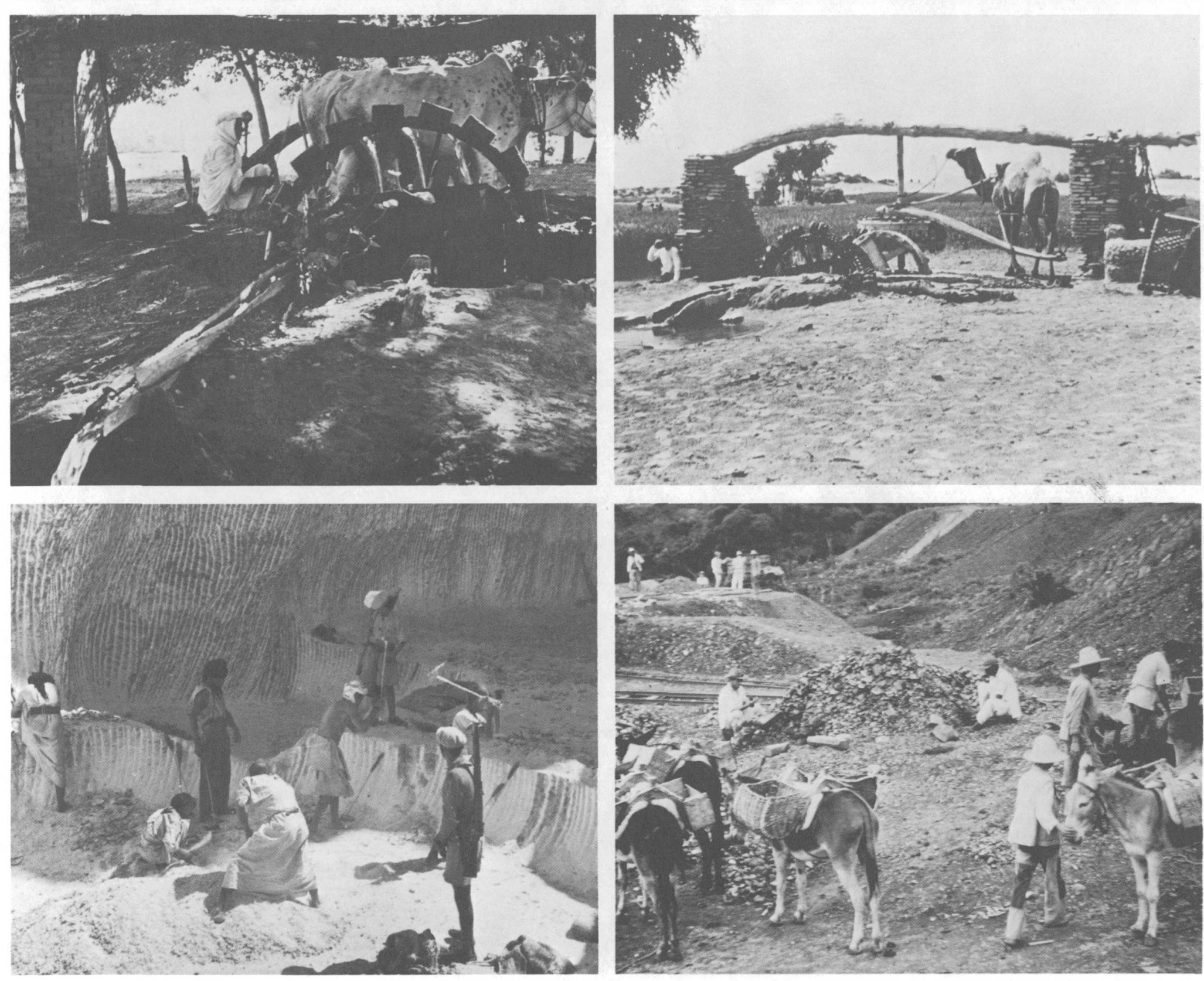
Concurrently, the Geological Survey continued to fulfill its domestic responsibilities. Recently, the public has become increasingly aware of natural geologic hazards.

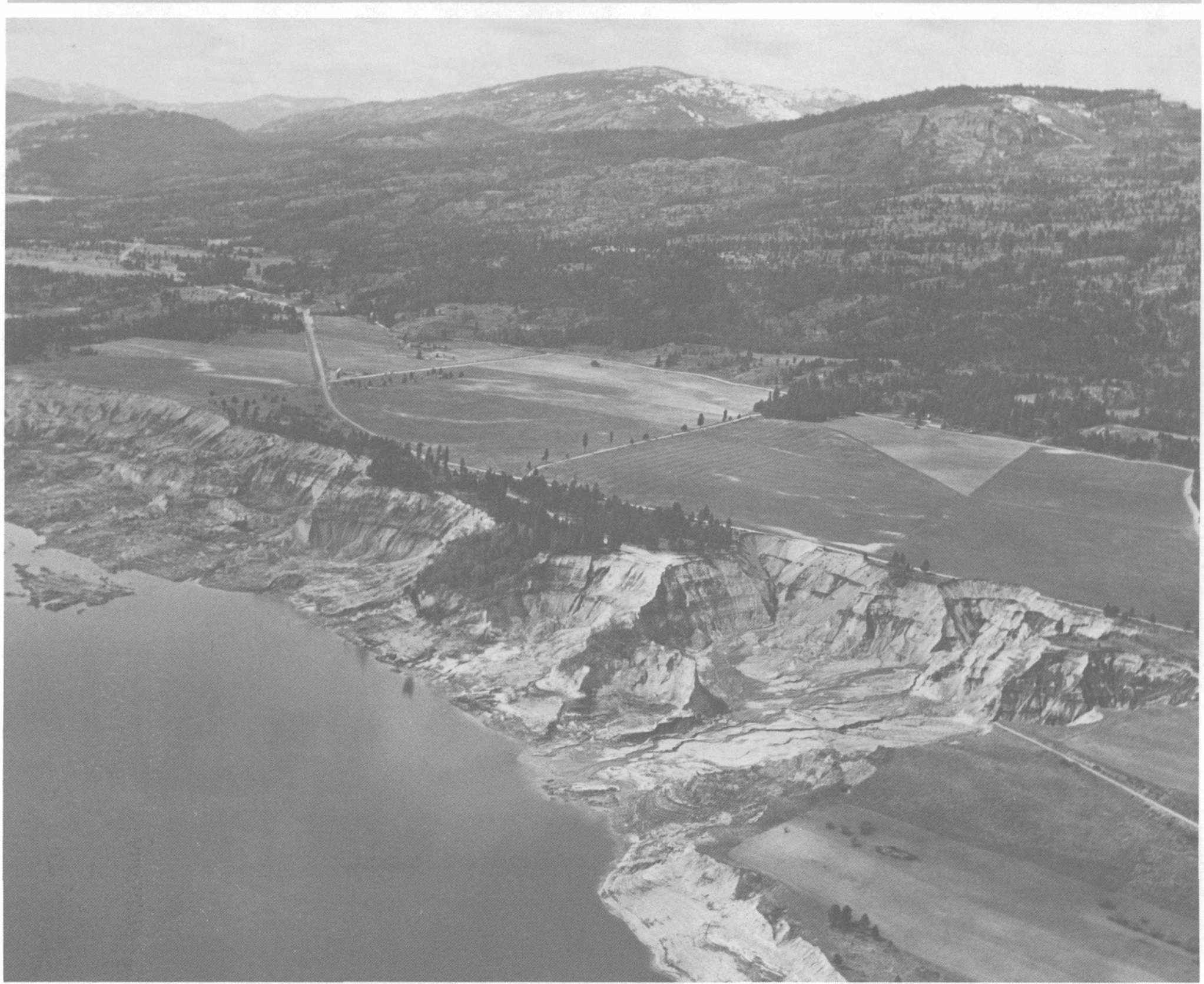

Engineering geology came into its own. 
Under the eighth Director, W. T. Pecora, earthquakes, the most dramatic of these hazards, were systematically investigated, and initial attempts were made to predict their occurrence.
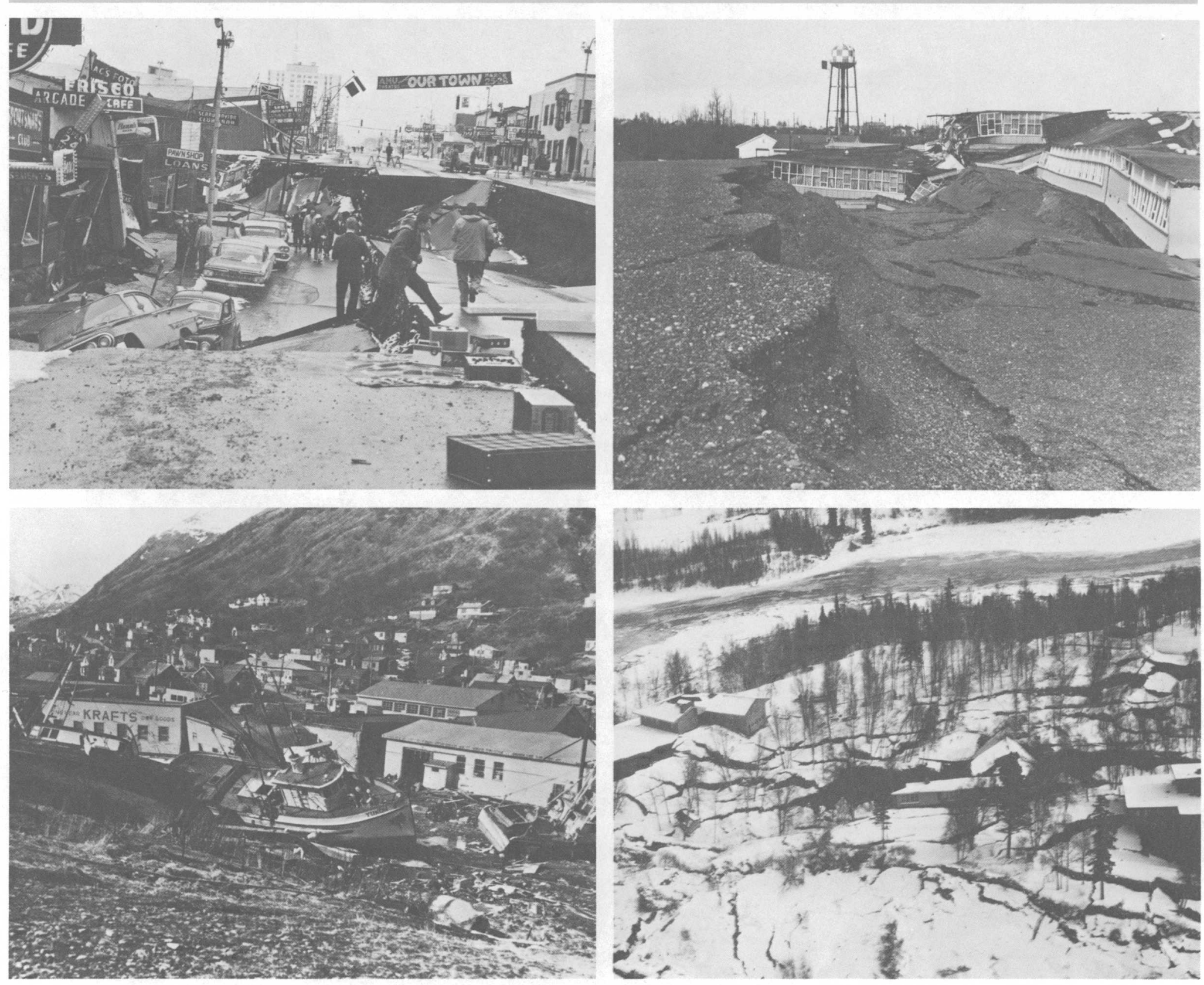

The 1964 Alaska earthquake expanded a long-standing interest in the dynamics of the Earth. 
V. E. McKelvey, the ninth Director, reemphasized the problems of water supply and quality and the coming shortages of minerals and liquid-gaseous fuels.

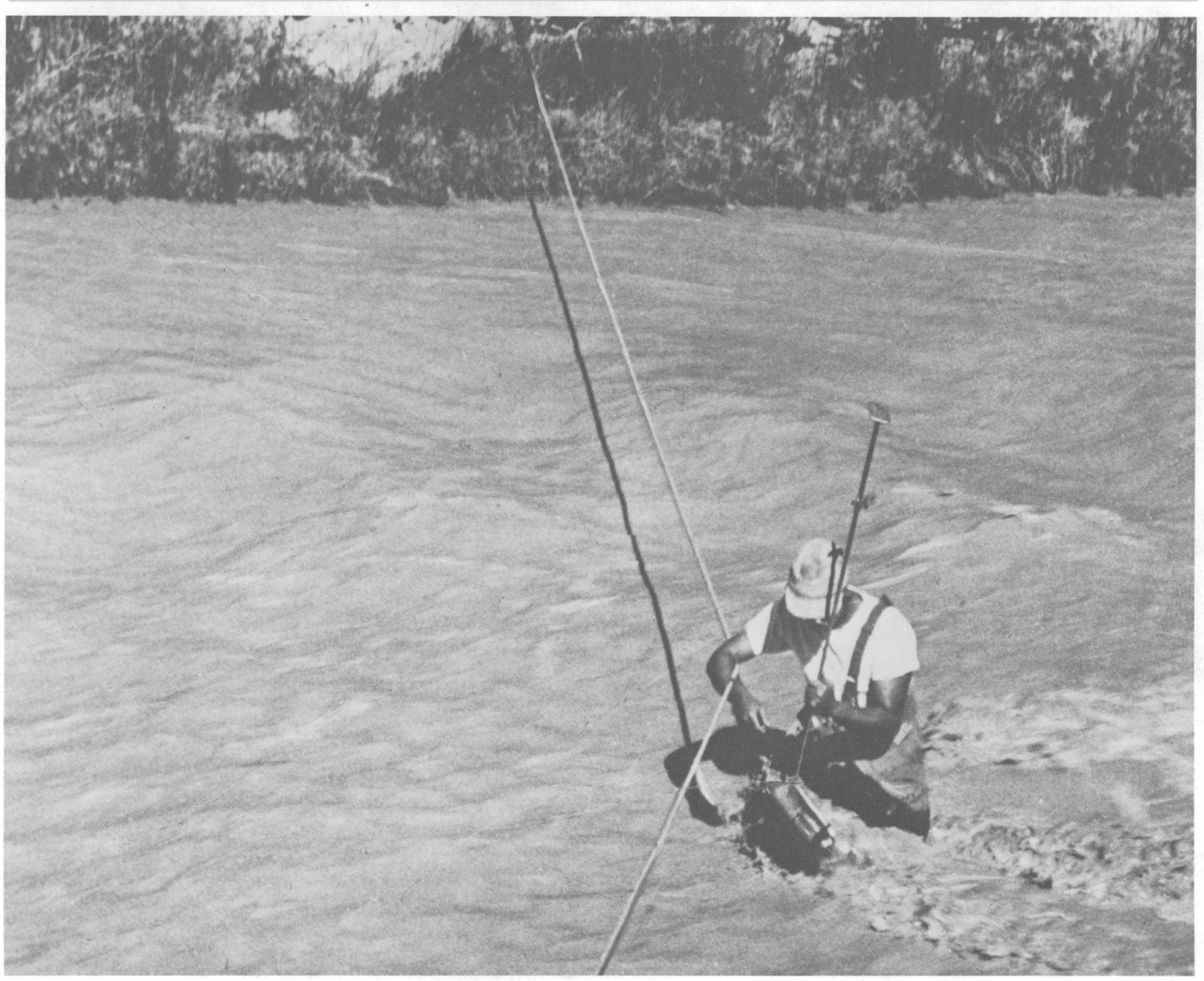




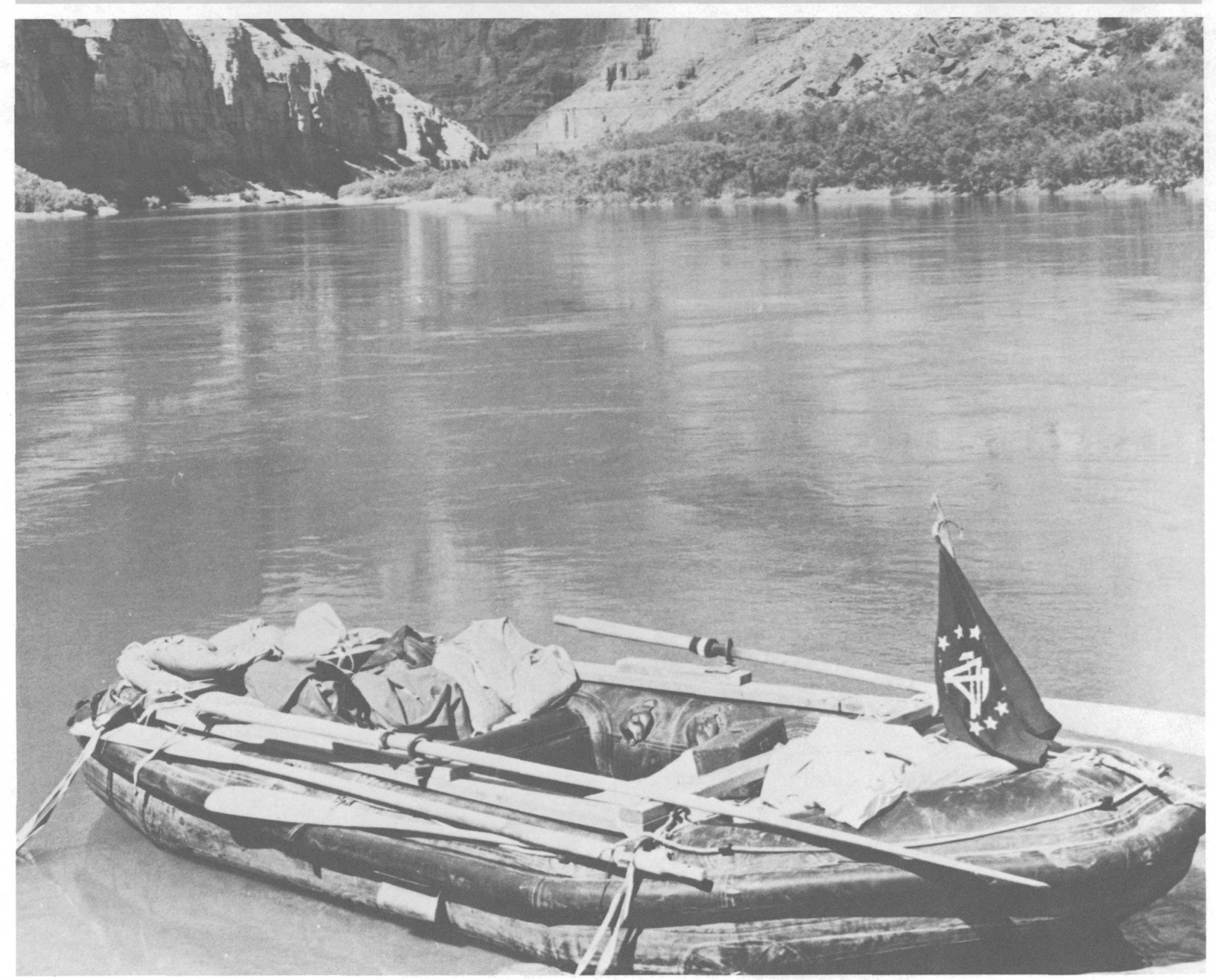




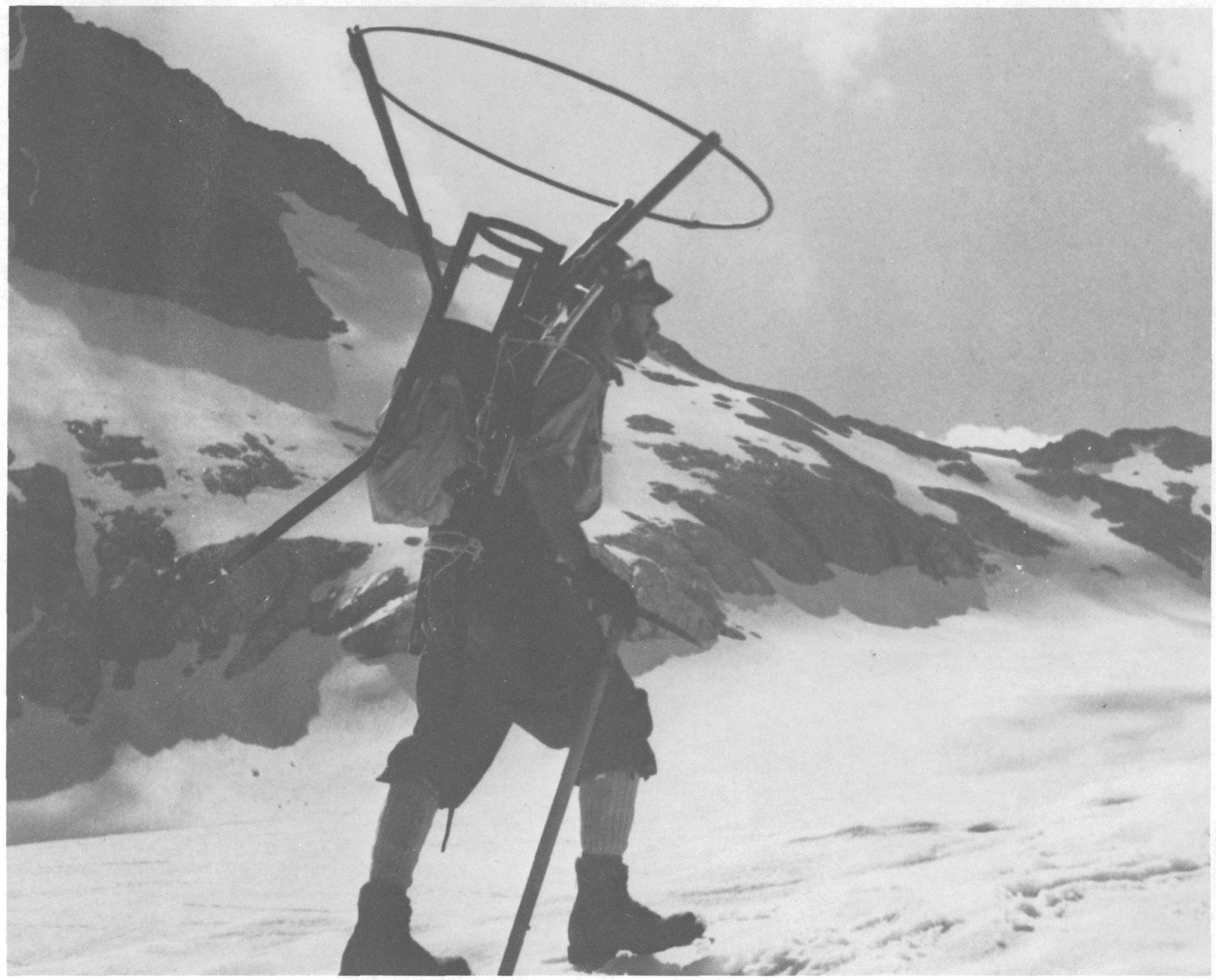


The concept that our natural resources are limited and must be wisely used and carefully conserved is becoming a matter of wide public knowledge and concern.

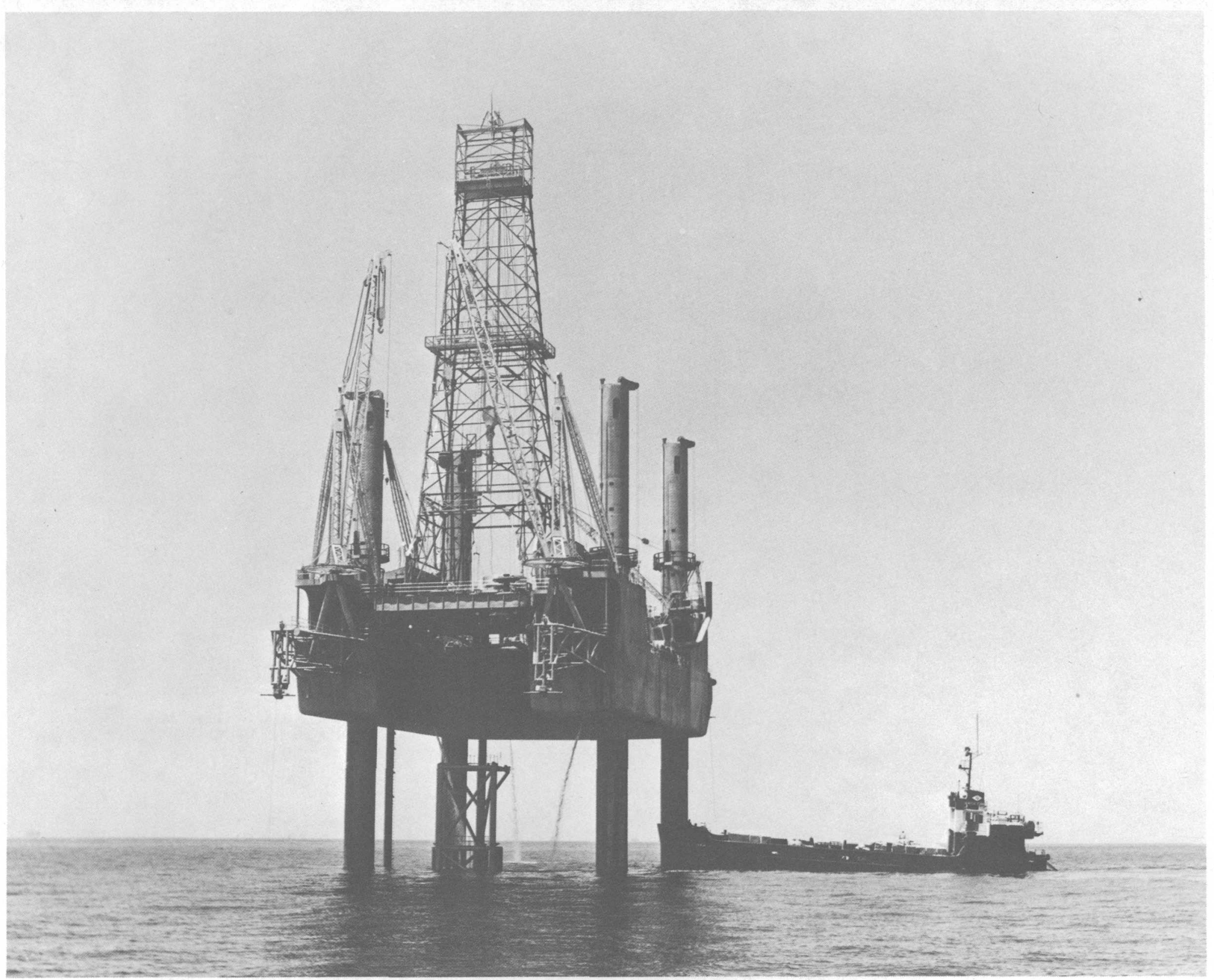

Today, limited natural resources must be evaluated, produced, and used wisely. 
The technique of applying interpretations of the rock record to analyses of the environmental problems of today is increasingly attractive.
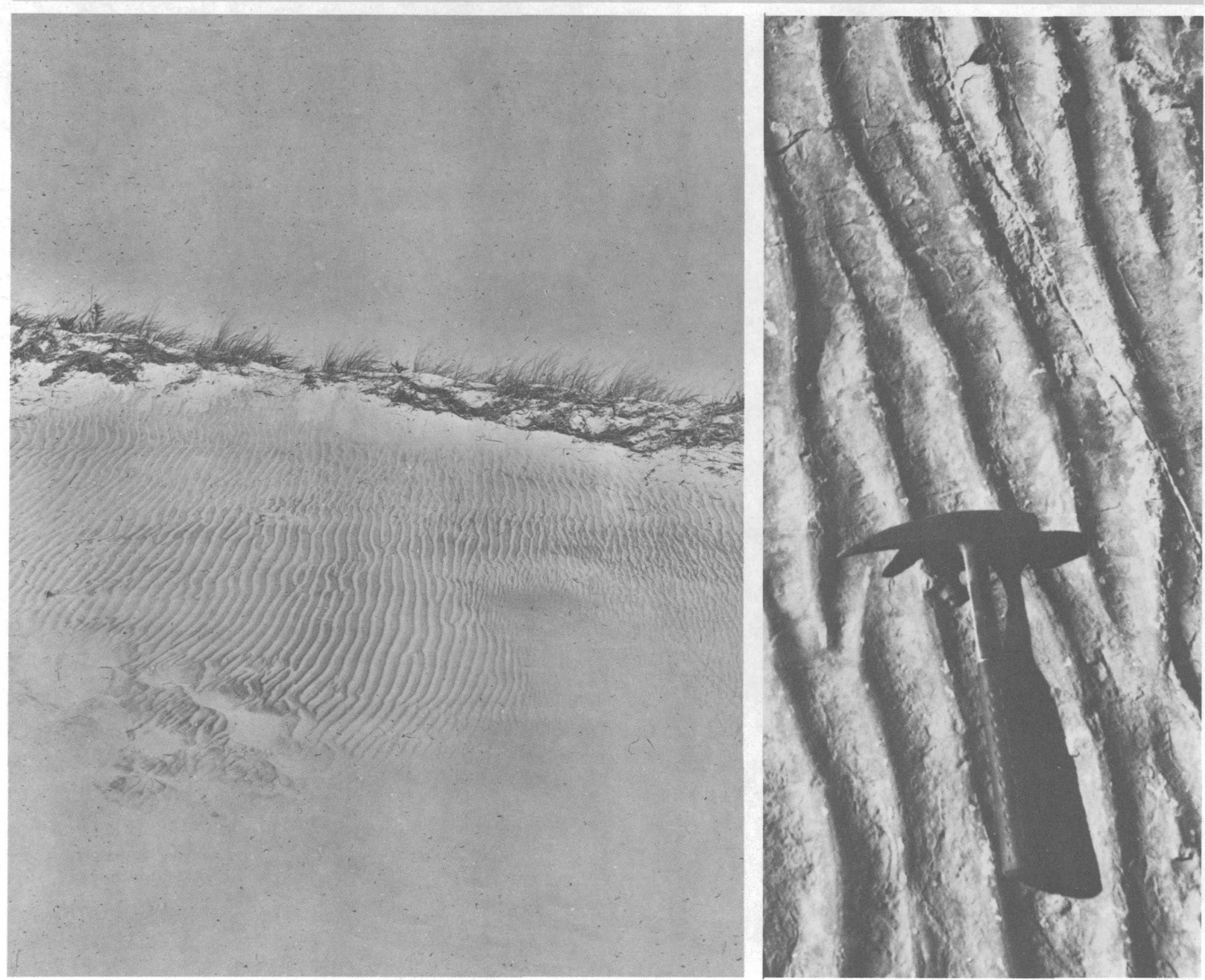

Modern geological processes still provide a key to the past 
Studies of the continental shelves and ocean basins, a postwar effort, are a special interest of H. W. Menard, the present Director of the Geological Survey.

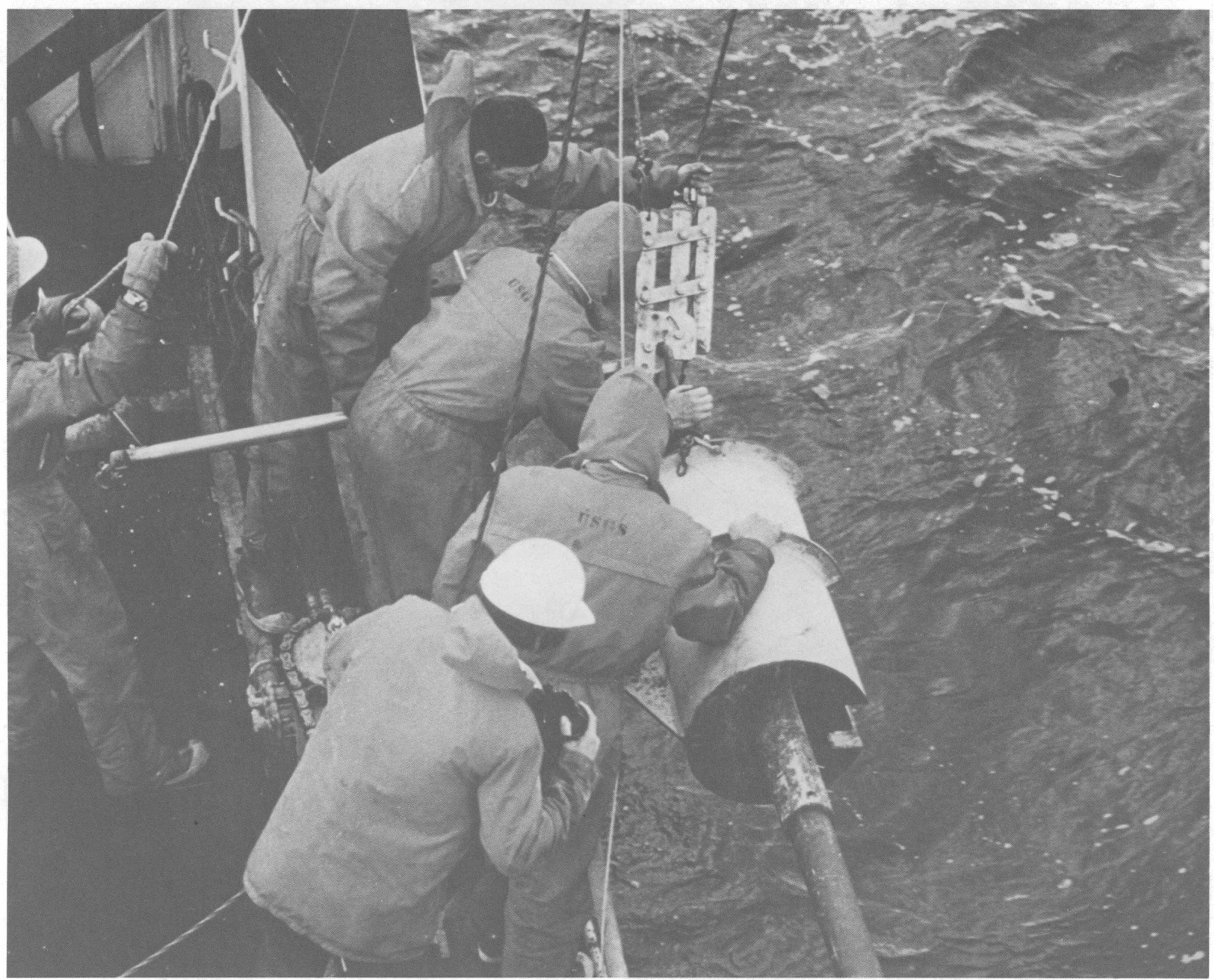


Meanwhile, the space age has yielded additional techniques and new vistas for the study of the Earth.

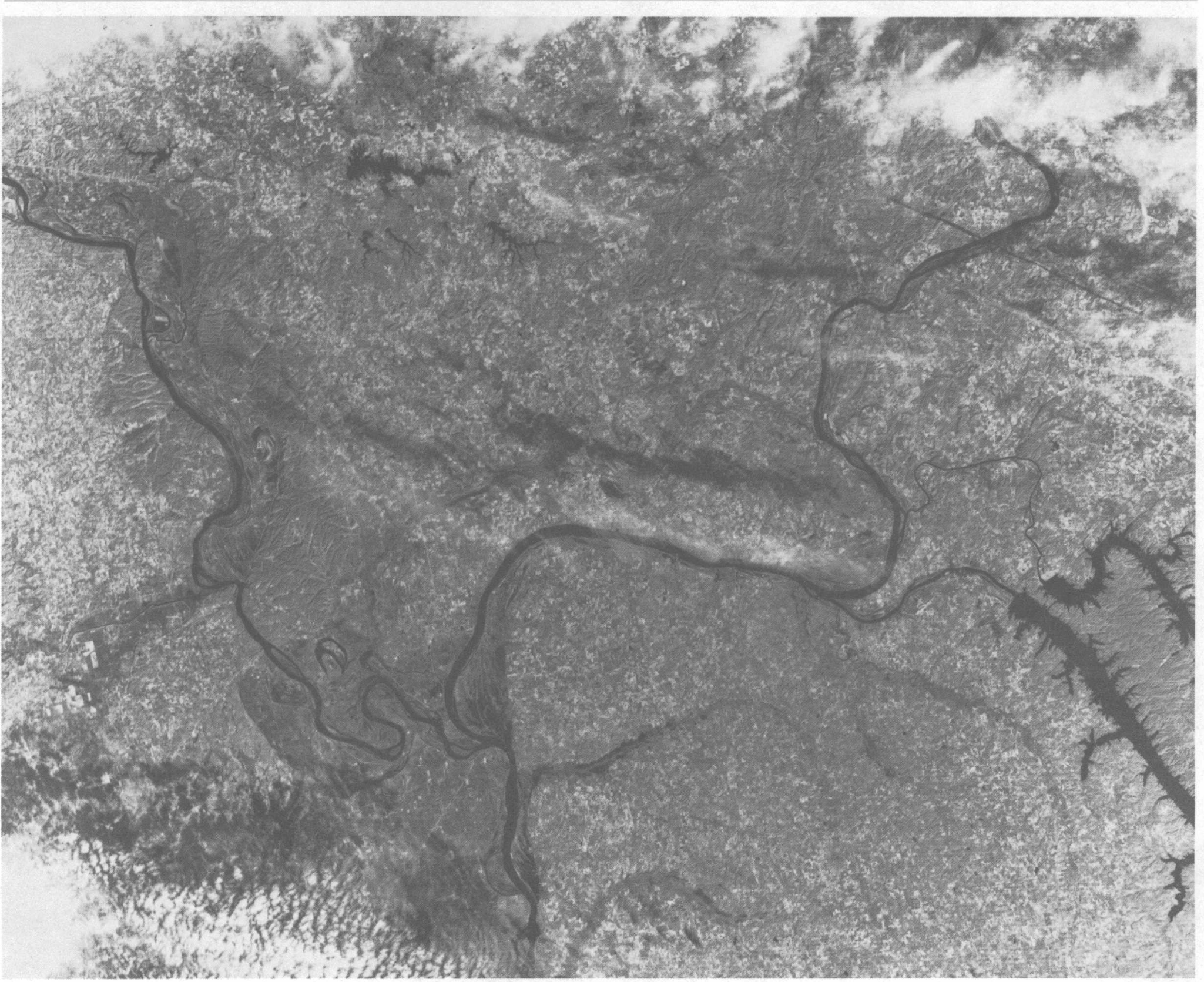




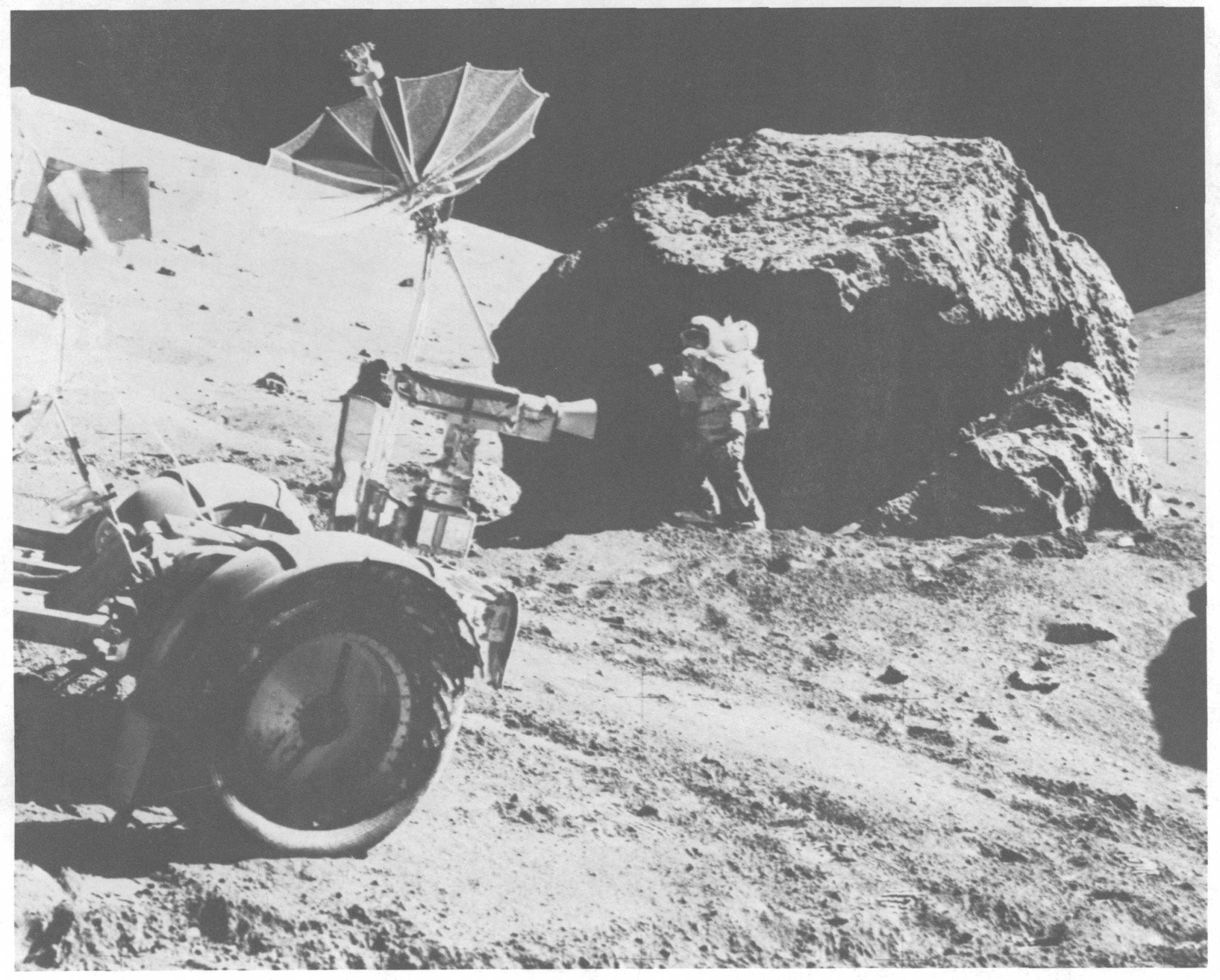




\section{Appendix}

The following captions provide more detailed information describing the photographs used in this publication, including the page number on which they appear.

Page 2.

Grand Canyon of the Colorado River, east from Grandview Point, Grand Canyon National Park, Coconino County, Arizona 1901 (photo by N. W. Carkhuff).

Page 3.

Upper Granite Gorge, downstream toward Sockdologer Rapids from cliff above Mineral Creek, Grand Canyon National Park, Coconino County, Arizona, 1923 (photo by L. R. Freeman).

Page 4.

Upper Left: Cripple Creek Mining District, Teller County, Colorado; Elkton Mine from Guyot Hill, 1903 (photo by F. L. Ransome).

Upper Right: Cripple Creek Mining District, Teller County, Colorado; Gold Hill from southwest slope of Tenderfoot Hill, 1903 (photo by F. L. Ransome).

Lower left: Cripple Creek Mining District, Teller County, Colorado; Bull Hill from Raven Hill, 1903 (photo by F. L. Ransome). Lower Right: Cripple Creek Mining District, Teller County, Colorado; Red Mountain and mines from road to Barstow Mine, 1900 (photo by F. L. Ransome)

Page 5.

Left: Crater of Lone Star Geyser, Arnold Hague on summit of cone, Yellowstone National Park, Wyoming, 1883 (photo by W. H. Jackson).

Right: Fossil tree trunks in life position, Fossil Forest, Specimen Ridge, Yellowstone National Park, Wyoming, 1896 (photo by J. P. Iddings)

Page 6.

Clayton Valley Salt Flat, from Mineral Ridge, near Silver Peak, Esmeralda County, Nevada, 1896 (photo by C. D. Walcott).

Page 7.

Lake Bonneville shoreline on east wall of Cache Valley, Logan quadrangle, Cache County, Utah, ca. 1901 (photo by

G. K. Gilbert).

Page 8.

Triangulation station on the summit of Garfield Peak, Rattlesnake Mountains, Natrona County, Wyoming, ca, 1913 (photo by C. J. Hares).

Page 9.

Topographic map-original scale: 1:24,000-and a photograph of a portion of Yosemite Valley, Yosemite National Park

Mariposa County, California, ca. 1906 (photographer unknown).

Page 10.

U.S. Geological Survey topographic leveling party, headed by R. A. Farmer, on the slopes of Mount Whitney, Cálifornia, ca. 1905 (photo by U.S. Department of Agriculture Experiment Station, Berkeley, California).

Page 11.

Left: Hooe Building, U.S Geological Survey, 1330 F Street NW., Washington, D.C., 1917 (photographer unknown).

Right: Adams Building, U.S. Geological Survey, 1333-1335 F Street NW., Washington, D.C., 1917 (photographer unknown).

Page 12.

Upper Left: R. K. Bailey performing a chemical determination of potash, Hooe Building, ca. 1917 (photographer unknown). Upper Right: M. Grace Wilmarth compiling data for a lexicon of stratigraphic names, Hooe Building, ca. 1917 (photographer unknown).

Lower Left: Personnel in publication and map distribution, Hooe Building, ca. 1917 (photographer unknown).

Lower Right: Pressroom personnel and presses, Adams Building, ca. 1917 (photographer unknown). 
Page 13.

Left: View of the southeast side of Natural Bridge, Rockbridge County, Virginia, 1891 (photo by C. D. Walcott).

Right: Boulder embedded in crystalline limestone, one mile north of Fort Ann, Washington County, New York, 1890 (photo by C. D. Walcott).

Page 14.

Robert Bridges standing in the arch of an anticline in Upper Silurian sandstones and shales, near the C \& O Canal, three miles west of Hancock, Washington County, Maryland, 1897 (photo by C. D. Walcott).

Page 15.

Anticlinal fold in Bailey Willis' beeswax model, originally 30 inches long, 6 inches wide, and 37/8 inches thick, after a horizontal compression of about 300 pounds, ca. 1891 (photo by J. K. Hillers).

Page 16.

Upper Left: U.S. Geological Survey field party in white sand ridges, Francis quadrangle, Wyoming, date unknown (photo by A. R. Schultz).

Upper Right: J. R. Hoats on horseback at McDermott Lake, Swiftcurrent Valley, Glacier National Park, Glacier County, Montana, ca. 1910 (photo by M. R. Campbell).

Lower Left: U.S. Geological Survey party near the House Range, north of Dome Pass, Millard County, Utah, 1903 (photo by C. D. Walcott)

Lower Right: U.S. Geological Survey camp near the mouth of Oh-Be-Joyful Gulch, Slate River Valley, Gunnison County, Colorado, 1909 (photo by W. T. Lee).

Page 17.

Placer mining, Gibbonsville, Lemhi County, Idaho, ca. 1899 (photo by Bailey Willis).

Page 18.

Upper Left: Pleistocene "Iroquois" shoreline near Pierrepont Manor, east of Lake Ontario, Jefferson County, New York ca. 1895 (photo by G. K. Gilbert).

Upper Right: Drumlins strewn with boulders, near West Plains, southwest Saskatchewan, Canada, 1932 (photo by W. G. Pierce).

Lower Left: Grooves and striations in glaciated ledge on the crest of the southeast slope of buried preglacial valley of the Nashua River, Marlboro quadrangle, Worcester County, Massachusetts, 1906 (photo by W. C. Alden).

Lower Right: Pitted terminal moraine topography, from the top of Black Hawk Bluff, 2 miles northeast of Prairie du Sac, Columbia County, Wisconsin, 1907 (photo by W. C. Alden).

Page 19.

Fossil palm leaf in sandstone, Coryell Coal Mines, Newcastle, Garfield County, Colorado, 1907 (photo by H. S. Gale).

Page 20.

Upper Left: Mount Olympus, Olympic Forest Reserve, Jefferson County, Washington, ca. 1898 (photo by T. F. Rixon). Upper Right: Forest in Skagit Valley, north of Hamilton, Skagit County, Washington, date unknown (photo by Bailey Willis). Lower Left: Logged-off torest on east slope of $B$ ig (photo by C. D. Walcott).

Lower Right: Loading logs on railroad car, Olympic Forest Reserve, Washington, ca. 1898 (photo by T. F. Rixon).

Page 21.

Panorama of Cascade Range from north to southwest, from summit of Mount Hawkins, Snoqualmie quadrangle, Kittitas County, Washington, date unknown (photo by Bailey Willis).

Page 22.

Cable-suspended, stream-gaging car used in measuring velocity of streams with a current meter, Arkansas River, near Canon City, Fremont County, Colorado, 1890 (photographer unknown).

Page 23.

Artesian well of the Riverside Water Company, near San Bernadino, San Bernadino County, California, ca. 1900 (photo by J. B. Lippincott).

Page 24.

Uncompahgre Irrigation Project, serving the Albin Ranch, 1 mile south of Table Mountain, southwest Colorado, date unknown (photo by U.S. Reclamation Service). 
Page 25

Left: A. H. Brooks examining a section of gold-bearing gravels and sands, Sweetcake Creek, tributary of Ophir Creek, Council District, Seward Peninsula, Alaska, 1900 (photographer unknown).

Upper Right: I. C. Russell leading a U.S. Geological Survey party across the moraines of the Malaspina Glacier, southeast Alaska, ca. 1890 (photographer unknown).

Lower Right: U.S. Geological Survey party hauling supplies upstream by canoe in Alaska, ca. 1910 (photo by P. S. Smith).

Page 26.

U.S. Geological Survey coal-testing plant in "Mining Gulch" at the Louisiana Purchase Exposition, St. Louis, Missouri, 1904 (photo by M. R. Campbell).

Page 27.

Oilfield in southern California, date unknown (photo by J. P. Lippincott).

Page 28.

Left: Oil shales in the Green River Formation (Eocene), northeast of Watson, Dragon quadrangle, Uintah County, Utah 1915 (photo by D. E. Winchester).

Right: U.S. Geological Survey geologists trench sampling part of the outcrop in the left photo, 1915 (photo by D. E. Winchester)

Page 29

Upper Left: U.S. Geological Survey camp at Horse Creek, Paradise Valley quadrangle, Bingham County, Idaho, 1923 (photo by G. R. Mansfield).

Upper Right: Trucking the Grand along the old Mormon "Dugway," opposite the mouth of the Paria River, Coconino County, Arizona, during the exploration of the Colorado River by a U.S. Geological Survey party led by Claude Birdseye, 1923 (photo by L. R. Freeman).

Lower Left: U.S. Geological Survey field vehicle used in the reconnaissance of the Papago country, southwest Arizona, 1920 (photo by Kirk Bryan).

Lower Right: Launching boats at the last camp, above Hance Trail, Colorado River, Grand Canyon National Park,

Coconino County, Arizona, during the Birdseye Expedition, 1923 (photo by L. R. Freeman).

Page 30 .

Personnel of the U.S. Geological Survey's Accounts Division, 1926 (photographer unknown).

Page 31.

Left: Water-data station on Columbia River, near Trinidad, Grant County, Washington (photographer and date unknown).

Upper Right: Truck-mounted current meter and sounding weight, on bridge over Mississippi River at Memphis,

Tennessee, 1938 (photographer unknown).

Lower Right: $\mathrm{O}$. H. Jeffers using reel and sled-mounted equipment to measure discharge through the ice of the

Mississippi River at St. Paul, Minnesota, ca. 1940 (photographer unknown).

Page 32.

Upper Left: Drilling for bauxite, Big Sandy Creek, Wilkinson County, Georgia, 1942 (photo by W. T. B. Lang).

Upper Right: G. M. Schwartz operating resistivity apparatus, locality and date unknown (photo by A. N. Sayre).

Lower Left: Northwest corner of Klondike Mine, near McIntyre, Wilkinson County, Georgia, ca. 1942 (photo by W. T. B.

Lang).

Lawer Right: C. B. Hunt (left) and K. E. Lohman (right) Military Geology Unit, US. Geological Survey, opening soil sample from the southwest Pacific, ca. 1945 (photographer unknown).

Page 33.

Monument Valley, with Oljeto Wash in the foreground and one of the Mittens and Mitchell Butte at right center, Navajo County, Arizona, ca. 1952 (photo by I. J. Witkind).

Page 34.

Dean Edson using an experimental Twinplex stereoscopic plotting instrument to build up map information from pairs of aerial photographs, Sacramento, California, ca. 1960 (photo by E. F. Patterson).

Page 35.

Upper. Left: DC-3 "flying laboratory" used in aeromagnetic surveys, National Airport, Washington, D.C., 1960 (photo by E. F. Patterson).

Upper Right: J. R. Balsley operating magnetometer in-flight, 1952 (photographer unknown). 
Lower Left: R. W. Bromery inspecting magnetometer detecting unit, 1960 (photo by E. F. Patterson).

Lower Right: Airborne magnetic survey of the Patuxent River area, Maryland, 1960 (photo by E. F. Patterson).

Page 36.

Upper Left: Geologic Division Laboratory, U.S. Geological Survey, Washington, D.C.; Irving Friedman and W. D. Long experimenting with welded volcanic tuffs, 1958 (photo by E. F. Patterson).

Upper Right: Geologic Division Laboratory, U.S. Geological Survey, Washington, D.C.; Henry Faul adjusting a sample of biotite at the focal point of a mass spectrometer, 1958 (photo by E. F. Patterson).

Lower Left: Geologic Division Laboratory, U.S. Geological Survey, Washington, D.C.; A. F. Hoyte operating a singlechannel analyzer to count the alpha particle disintegrations in a specimen for radiometric-age determination, 1958 (phato by E. F. Patterson).

Lower Right: Geologic Division Laboratory, U.S. Geological Survey, Washington, D.C.; Isidore Adler operating a

goniometer used in $\mathrm{X}$-ray fluorescence analysis of individual grains in mineral specimens, 1958 (photo by $\mathrm{E}$. F. Patterson)

Page 37.

Left: Outcrop of Dakota Sandstone, of Cretaceous age, above Crater Lake Base Camp, Philmont Scout Ranch area, Tooth of Time quadrangle, Colfax County, New Mexico, 1958 (photo by J. R. Stacy).

Upper Right: G. D. Robinson examining an outcrop of the Chinle Formation (Triassic), Cimarroncito Creek, Philmont Scout Ranch, Colfax County, New Mexico, 1958 (photo by E. F. Patterson).

Lower Right: Measuring dip of Dakota Sandstone above Crater Lake Base Camp, Philmont Scout Ranch area, Tooth of

Time quadrangle, Colfax County, New Mexico, 1958 (photo by J. R. Stacy).

Page 38.

Sampling gases of freshly extruded lava from Kilauea Volcano, Hawaii, 1974 (photo by R. T. Holcomb)

Page 39.

Pyramid Mountain and west wall of Beacon Dry Valley, Taylor Glacier region, Victoria Land, Antarctica, 1958 (photo by P. T. Hayes)

Page 40.

Sand dunes in the Ubari Sand Sea, between Brach and Ubari, Fezzan district, southwest Libya, ca. 1958 (photo by G. H. Goudarzi).

Page 41

Upper Left: Persian water wheel, Indus Plains, Pakistan, ca. 1967 (photo by F. E. Clarke)

Upper Right: Persian water well, Pakistan, ca. 1963 (photo by J. W. Hood).

Lower Left: Excavating salt at Lai'adin Salt Dome, Aden Protectorate (South Yemen), Arabian Peninsula, ca. 1961 (photo by J.E. G. W. Greenwood).

Lower Right: Hauling chrome ore to Campo Formoso, Bahia, Brazil, 1941 (photo by W. D. Johnston, Jr.).

Page 42.

Landslide scars, near Franklin D. Roosevelt Lake, just south of the mouth of Sherman Creek, Ferry County, Washington, 1953 (photo by F. O. Jones).

Page 43.

Upper Left: Collapse of Fourth Avenue near C Street, Anchorage, Alaska, after earthquake, 1964 (photo by U.S. Army Corps of Engineers).

Upper Right: Wreckage of Government Hill School, Anchorage, Alaska, as viewed looking west from playground, 1964 (photo by U.S. Army Corps of Engineers).

Lower Left: Numerous vessels washed ashore into the heart of Kodiak, Alaska, by tsunamis following earthquake, 1964 (photo by U.S. Army Corps of Engineers).

Lower Right: Landslide damage in Turnagain Heights area, Anchorage, Alaska, following earthquake, 1964 (photo by U.S. Army Corps of Engineers).

\section{Page 44.}

Depth-integrating sediment sampler attached to a wading rod, locality unknown, ca. 1955 (photo by B. R. Colby).

Page 45.

Rubber raft used in a resurvey of the Colorado River, in Marble Canyon, near the mouth of Little Nankoweap Creek,

Coconino County, Arizona, 1968 (photo by H. G. Stephens). 
Page 46.

Scott Wesley backpacking a mountain precipitation gage on South Cascade Glacier, Chelan and Skagit Counties, Washington, 1961 (photographer unknown).

Page 47.

Mobile drilling platform "Mr. Gus II," on Outer Continental Shelf lease 0134, Block 48, Grand Isle area, off Louisiana, 1957 (photo by E. F. Patterson).

Page 48.

Left: Wind ripple marks on the face of a sand dune, Washington County, Rhode Island, ca. 1900 (photo by C. D. Walcott) Right: Ripple marks on Dakota Sandstone in Jefferson County, Colorado, 1966 (photo by J. R. Stacy).

Page 49.

Piston coring from R/V Sea Sounder, in the Gulf of Alaska, by members of the U.S. Geological Survey, 1977 (photo by P. R. Carlson).

Page 50.

Landsat-1 image (1124-16061, band 7) showing the Mississippi and Ohio Rivers on November 24, 1972

Page 51.

H. H. "Jack" Schmitt at Station 6, Taurus-Littrow Valley, Apollo XVII Lunar Mission, 1972 (photo by E. A. Cernan).

Credit:

Photo research by Marjorie E. Dalechek, Denver PhotoLibrary, Denver, Colorado.

Earth science information and data are essential to balance the wise use and conservation of our lands, energy, mineral, and water resources, and to maintain and improve environmental quality during the next century.

This publication is one of a series of general interest publications prepared by the U.S. Geological Survey to provide information about the earth sciences, natural resources, and the environment. To obtain a catalog of additional titles in the series "Popular Publications of the U.S. Geological Survey," write:

$$
\begin{array}{ll}
\text { Branch of Distribution or } & \text { Branch of Distribution } \\
\text { U.S. Geological Survey } & \text { U.S. Geological Survey } \\
1200 \text { South Eads Street } & \text { Box 25286, Federal Center } \\
\text { Arlington, VA 22202 } & \text { Denver, CO } 80225
\end{array}
$$


As the Nation's principal conservation agency, the Department of the Interior has responsibility for most of our nationally owned public lands and natural resources. This includes fostering the wisest use of our land and water resources, protecting our fish and wildlife, preserving the environmental and cultural values of our national parks and historical places, and providing for the enjoyment of life through outdoor recreation. The Department assesses our energy and mineral resources and works to assure that their development is in the best interests of all our people. The Department also has a major responsibility for American Indian reservation communities and for people who live in Island Territories under U.S. administration
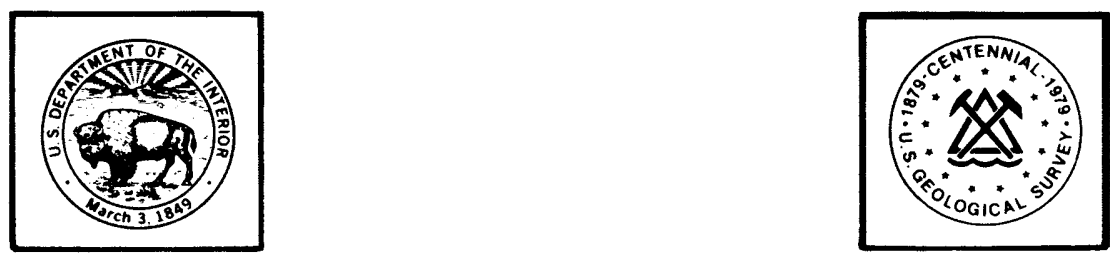